Max-Planck-Institut für demografische Forschung

Max Planck Institute for Demographic Research

Konrad-Zuse-Strasse 1 - D-18057 Rostock · GERMANY

Tel +49 (0) 3812081 - 0; Fax +49 (0) 3812081 - 202;

http://www.demogr.mpg.de

MPIDR WORKING PAPER WP 2005-006

MARCH 2005

The contextual database of the generations

and gender program in Bulgaria: concep-

tual framework and an overview of the

Bulgarian context concerning the central

database topics

Martin Spielauer (spielauer@ demogr.mpg.de)

Dora Kostova

Tatyana Kotzeva

Vetka Jekova

Kremena Borissova

This working paper has been approved for release by: Vladimir M. Shkolnikov (shkolnikov@ demogr.mpg.de),

Head of the Laboratory for Demographic Data.

(C) Copyright is held by the authors.

Working papers of the Max Planck Institute for Demographic Research receive only limited review. Views or opinions expressed in working papers are attributable to the authors and do not necessarily reflect those of the Institute. 


\title{
The Contextual Database of the Generations and Gender Program in Bulgaria: Conceptual Framework and Overview of the Bulgarian Context as to the Central Database Topics
}

\author{
Martin Spielauer \\ Dora Kostova* \\ Tatyana Kotzeva* \\ Vetka Jekova* \\ Kremena Borissova*
}

\begin{abstract}
This paper outlines the concept and content of the Contextual Database of the international Generations and Gender Program and gives an overview of the context of demographic behavior in Bulgaria.

The Contextual Database provides an instrument that together with the Generations and Gender Survey allows studying how differences in context shape demographic processes. The database offers the opportunity to analyze in a comparative way the interaction between the micro and macro dimension.

Bulgaria is among the first countries fielding the Generations and Gender Survey and that is engaged in contextual data collection within this comparative framework. While both micro- and contextual data for Bulgaria will become available in the course of the year 2005, we present in this paper a text contribution that provides an overview of the Bulgarian context and introduces the list of variables that make up the database.
\end{abstract}

*This paper is the joint work of researchers of the *Center for Population Studies of the Bulgarian Academy of Science who are also responsible for a substantial part of the data collection and Martin Spielauer, head of the international working group responsible for the development of conceptual framework of the database. 


\section{Introduction}

This paper aims at introducing the concept and content of the Contextual Database of the international Generations and Gender Program and providing an overview of the context of demographic behavior in Bulgarian as studied within this comparative framework.

The Generations and Gender Contextual Database (CDB) is an integral part of the international Generations and Gender Program (GGP) coordinated by the Population Activities Unit (PAU) of the United Nations' Economic Commission of Europe. The main part of this program is the Generations and Gender Panel Survey (GGS). In Bulgaria, the fieldwork of the first round of this survey started in November $2004^{1}$. The contextual database is a comparative collection of data on a national and sub-national level complementing the individual-level data collected in the GGS. The database enables the analysis of micro-level information collected from individuals in its societal macro-level context. It includes information on laws and policies that effect age and sequencing norms as well as the consequences and risks associated with the central life-course events studied in the GGP. It also includes indicators of general gender and generational relations, and a range of social, economic and political indicators. The CDB allow to go beyond the analysis of single countries, considering how differences in context shape the demographic processes, and offering the opportunity to study in a comparative way the interaction between the micro and macro dimension. The CDB will be freely available for the scientific community via internet.

The idea of the development of a contextual database to complement the data collection on the individual level was expressed as early as in the Family and Fertility Survey program, which preceded the Generations and Gender Program. It was driven by the desire to go beyond the analysis of single countries and to consider how differences in context shape the processes that seem to be having an impact on these new family pattern' (Goldscheider 2000). More generally, it is based on (1) the increasing recognition that micro behavior cannot be explained only by relations observed on the micro level and (2) an increasing interest in comparative research. 'Designing a Macro-Context for the Generations and Gender Individual Data' was also the topic of a contribution by Patrick Festy (2001) presented at the first meeting of the Generations and Gender Informal Working Group in $2001^{2}$. With the installation of the Contextual Database Working Group in 2002, the development of a contextual database became an integral part of the Generations and Gender Program.

\footnotetext{
${ }^{1}$ The GGS or variants of it are conducted or planned to be conducted in the following countries: Austria, Bulgaria, the Czech Republic, France, Georgia, Germany, Hungary, Italy, Japan, Lithuania, Poland, Romania, and Russia; additional countries are expected to follow.

${ }^{2}$ Patrick Festy coordinated the Contextual Database Group from its establishment until mid 2003.
} 
While contextual information has always been of importance in demographic analysis, the way it is linked to demographic events has changed over time. Historically, demographic research moved from the macro to the micro level of analysis towards an integration of levels, a move that is paralleled both by developments in analytical methods and new ways of data collection. The Generations and Gender Program is an innovative step in this direction.

Bulgaria is among the first countries fielding the Generations and Gender Survey and engaged in contextual data collection within this comparative framework. Both micro- and contextual data for Bulgaria will become available in the course of the year 2005. This paper provides an overview of the Bulgarian context and we introduce the list of variables that make up the database.

This paper is organized as follows. We first start from the Generations and Gender Survey and its information content in order to identify the most important contextual domains the database topics - which closely relate to the individual-level information collected in the survey. Subsequently, we introduce the conceptual framework of the Contextual Database that lead to the identification of the variable lists by database topic. (The full list of variables can be found in the Appendix) After this theoretical introduction of the database, we, third, describe its general focus and coverage for each of its 16 contextual domain together with an overview of the Bulgarian context concerning these topics.

\section{The information content of the GGS and its link to contextual data}

In this paragraph, we aim at describing the survey in a way that supports the identification of the interfaces of the collected individual data with contextual data. In order to do so, we will look at the data from various perspectives. We will start from a life-course perspective that is very useful regarding the structuring of complex individual data by different life course domains and by time. We will then look at the dimensions of personal relations captured by the survey. The GGS collects detailed data on labor-market activity, home production (care, household tasks etc.) and related exchange relations. It also includes public transfers, pensions, and other benefits as well as used institutional care and childcare services. These variables connect the individual situation to the broader context of the welfare state, and we will use a welfare state perspective in the analysis of related aspects. Following this route, we will cover all collected variables, highlight the main dependent variables and the key links and interfaces of the micro- and contextual data.

\subsection{The individual life course and its context}

The life course refers to a sequence of socially defined events and roles that the individual enacts over time. These roles and the transitions from one role to another are central issues in the GGS and constitute key dependent variables. Contrary to the life-cycle concepts, 
which are widely used, e.g. in economics or psychology, and which are based on a predetermined "typical" sequence of roles, episodes of life or expected behaviors, the lifecourse concept permits the study of changing role patterns and of the interactions between different domains or careers, such as education, jobs, partnerships, births and disability. Key elements of the life course paradigm are human agency and individual goal orientation as well as "strategic adaptation", by the timing of events in the presence of conflicting goals. In demographic research, the life-course framework links the traditional concepts of period, age and cohort to the fourth component of the timing of lives. The life course perspective also goes hand in hand with a certain description of human biographies as event histories with clearly defined states and events belonging to different domains. In the GGS, we can distinguish several of such domains, many of them further distinguishing events by various dimensions. We can distinguish five main careers ${ }^{3}$ (or domains)

- The "Life" career, with a "general" dimension - being alive, res. the events birth and death - and the health dimension, with survey data collected on illnesses, disabilities, care needs, wellbeing and some limited history information. Information on limitations in daily activities is collected for all household members as well as for parents and children in order to obtain information on possible care needs in the family network.

- Activity careers: The survey distinguishes various main activities, such as working, retirement, on parental leave, unemployed, in education. Information on the main activity is collected for all household members. The questions regard the respondent's and partner's current job and/or education and intentions to start or resume work, e.g. after leave periods. Full histories are planned to be collected at the second wave.

- Residential careers, with the dimensions of geographical location, dwelling type and living arrangements (co-residence). The first wave of the GGS only collects limited biographical information, such as the place of birth, the main living arrangement until age 15 etc., but detailed information on the current status and intentions of changing the dwelling, location and/or living arrangements.

- Partnership careers, with the dimensions of legal relation and co-residence. The GGS contains a full history of co-residing partnerships, marriages and divorces. Extensive information is collected on the current partner, especially on the activity status, income and fertility.

- Fertility careers, with the dimensions of fecundity and births, including current pregnancies. The GGS contains full birth histories. Due to the increasing age at birth in many countries, a high emphasis is placed on questions regarding fertility treatment. With births being one of the key dependent variables, extensive information is collected also on fertility intentions.

\footnotetext{
${ }^{3}$ This classification is only one of various possible categorizations
} 
The following table displays the main questionnaire content by career domains and dimensions, and further distinguishes by time retrospective questions, the current state and prospective questions and intentions.

\begin{tabular}{|c|c|c|c|c|}
\hline Domain & Dimension & Retrospective & Current & Prospective \\
\hline \multirow[t]{2}{*}{ Life } & General & $\begin{array}{l}\text { Birth, death (partner, parents, } \\
\text { children) }\end{array}$ & & \\
\hline & health related & Disabled and illness since & $\begin{array}{l}\text { Disabilities, health status, } \\
\text { illness, need for personal care, } \\
\text { wellbeing }\end{array}$ & Expected locus of control \\
\hline \multirow[t]{5}{*}{ Activity } & $\begin{array}{l}\text { All (work, } \\
\text { leave, } \\
\text { education, } \\
\text { military/civil } \\
\text { service, } \\
\text { unemployed, } \\
\text { retired, home- } \\
\text { keeper) }\end{array}$ & In current state since & Current activity; satisfaction & \\
\hline & Work & $\begin{array}{l}\text { Worked last week? Why } \\
\text { stopped last job? }\end{array}$ & $\begin{array}{l}\text { Various job characteristics: } \\
\text { type, sector, hours, position, } \\
\text { flexibility; additional job(s), } \\
\text { satisfaction with job security }\end{array}$ & $\begin{array}{l}\text { Intention to give up or change } \\
\text { job, for all not currently working: } \\
\text { intention to start or resume work }\end{array}$ \\
\hline & Education & Highest \& completion date & & $\begin{array}{l}\text { Intention to finish or resume } \\
\text { education }\end{array}$ \\
\hline & Retirement & Date & & $\begin{array}{l}\text { Intention to retire, including } \\
\text { opinions of others, factors that } \\
\text { influence decision; assumed } \\
\text { consequences }\end{array}$ \\
\hline & $\begin{array}{l}\text { Parental \& } \\
\text { care leave }\end{array}$ & $\begin{array}{l}\text { History (with which children on } \\
\text { leave) }\end{array}$ & Type of leave & $\begin{array}{l}\text { Possibility and intention to } \\
\text { resume work }\end{array}$ \\
\hline \multirow[t]{3}{*}{$\begin{array}{l}\text { (Co-) } \\
\text { Residence }\end{array}$} & Place & $\begin{array}{l}\text { Place of birth and at age } 15 ; \text { in } \\
\text { country since }\end{array}$ & & \multirow[t]{2}{*}{$\begin{array}{l}\text { Intention to move including } \\
\text { destination }\end{array}$} \\
\hline & Dwelling & Since & $\begin{array}{l}\text { Ownership and number of } \\
\text { rooms; satisfaction }\end{array}$ & \\
\hline & Arrangement & & & $\begin{array}{l}\text { Intention to leave parental home } \\
\text { and/or to move together with a } \\
\text { partner including opinions of } \\
\text { others; factors that influence } \\
\text { decision; assumed } \\
\text { consequences }\end{array}$ \\
\hline \multirow[t]{3}{*}{ Partnerships } & $\begin{array}{l}\text { Current } \\
\text { partnership }\end{array}$ & $\begin{array}{l}\text { Date of moving together and } \\
\text { marriage }\end{array}$ & \multicolumn{2}{|c|}{$\begin{array}{l}\text { Quality of partnership; disagreements and handling of conflicts; } \\
\text { thought about break-up? }\end{array}$} \\
\hline & Legal & $\begin{array}{l}\text { Full history of marriages and } \\
\text { divorces; who started process } \\
\text { of divorce; location of children } \\
\text { after break-up }\end{array}$ & & Intention to marry \\
\hline & Co-residence & $\begin{array}{l}\text { Full history of partnerships in co } \\
\text { residence; reason for } \\
\text { dissolution }\end{array}$ & & $\begin{array}{l}\text { Intention to move together with a } \\
\text { partner including opinions of } \\
\text { others; factors that influence } \\
\text { decision; assumed } \\
\text { consequences }\end{array}$ \\
\hline \multirow[t]{3}{*}{ Fertility } & $\begin{array}{l}\text { Current } \\
\text { pregnancy }\end{array}$ & \multicolumn{2}{|c|}{$\begin{array}{l}\text { When stopped contraception; begun fertility treatment; wanted? } \\
\text { Wanted from partner? }\end{array}$} & Expected birth date \\
\hline & Fecundity & $\begin{array}{l}\text { When detected inability to have } \\
\text { children; sterilization; treatment } \\
\text { since; contraception since }\end{array}$ & Current status & \\
\hline & Births & Full history & & $\begin{array}{l}\text { Intention to have another child in } \\
\text { next } 3 \text { years, in general, total } \\
\text { number; including opinions of } \\
\text { others, factors that influence } \\
\text { decision and assumed } \\
\text { consequences; intentions to } \\
\text { adopt children }\end{array}$ \\
\hline
\end{tabular}


As shown in the table above, the main dependent variables of the survey are childbearing, union formation and dissolution, transition to adulthood and living arrangements. Given the broad coverage of intentions, dependent variables can be both retrospective events and intentions - with the full power of the survey unfolding with the subsequent panel wave, which will substantially extend the scope of possible analysis (e.g., of the circumstances that influence the realization of intentions).

How do these individual data relate to context? The description of individual lives by means of event history data is not independent of the context. The possibility to meaningfully describe individual biographies that way is a result of societal differentiation, which leads to a structure of the life course in segmented roles. These roles are therefore not independent of the macro context of life, such as the welfare state and its institutions. There exists a mapping of the institutional differentiation on the macro level of societies onto life domains and the segments of the life course. For example, the activity status "on parental leave" depends on the existence of parental leave regulations. This places individual choices into a context that might vary considerably between countries. The following table highlights the key micro-macro links between life course states and macro level institutions.

\begin{tabular}{|c|c|c|}
\hline & Micro state / event & Macro system \\
\hline \multirow[t]{7}{*}{ Activity Status } & Employed & Labor market \& employment system \\
\hline & Unemployed & Unemployment insurance \\
\hline & $\begin{array}{l}\text { Military \& civil } \\
\text { service }\end{array}$ & $\begin{array}{l}\text { Defense system and (alternative) service } \\
\text { regulations }\end{array}$ \\
\hline & $\begin{array}{l}\text { Maternity \& care } \\
\text { leave }\end{array}$ & Leave regulations \\
\hline & Student & Education system \\
\hline & Retired & Retirement system \\
\hline & Home keeper & $\begin{array}{l}\text { Tax system, social insurance of dependent } \\
\text { family members }\end{array}$ \\
\hline \multirow[t]{3}{*}{ Marital Status } & Married & $\begin{array}{l}\text { Marriage regulations \& obligations; tax } \\
\text { treatment of married couples; incentive } \\
\text { system for unmarried \& single parenthood }\end{array}$ \\
\hline & Divorced & Divorce regulations; alimonies \\
\hline & Widowed & Widowed pension \\
\hline Parenthood & Pregnancy & $\begin{array}{l}\text { Maternity leave system; job protection; } \\
\text { abortion laws; birth preparation system }\end{array}$ \\
\hline
\end{tabular}


(health checks etc.)

Parent $\quad$-> Relations

Health status Restricted in daily Health \& elderly care system activities; in need of care

Sick Health insurance system

\subsection{Gender and generational relations and their context}

With it being a "Generations and Gender" Survey, gender and (inter-)generation relations constitute a key area of information collected in the survey. Persons for whom information is collected include all persons in the household, all (ex-) partners, children and parents as well as other persons if they are important providers or receivers in the captured exchange relations (see below). Personal relations are investigated in various dimensions:

- Legal: nature of legal relation such as married, adopted.

- Co-residence: does the person currently live in the household, when did he or she enter or leave the household or vice versa?

- Intensity: how often does the respondent meet the person, how far does he or she live away?

- Satisfaction: how satisfied is the respondent with the relation?

- Quality: some questions aim at measuring the quality of relations, like the occurrence and the way of settling certain problems etc.

- Power and decision making: who decides on the organization of household tasks and childcare or on spending?

- Care relations: main providers and receivers of care, including emotional support.

- Economic exchange: both regarding money (who contributes what to the household income, who decides on spending; transfers and alimonies) and concerning the household production of child and elderly care as well as diverse household tasks.

The economic dimension of gender- and intergenerational relations can be regarded as one of the key areas of the survey. Household production, especially regarding the organization, production and the exchange of care are a central link between gender and generational relations. 


\begin{tabular}{lll}
\hline & $\begin{array}{l}\text { Relational } \\
\text { dimension }\end{array}$ & Macro context \\
\hline $\begin{array}{l}\text { Household } \\
\text { production }\end{array}$ & $\begin{array}{l}\text { Organization of } \\
\text { child care }\end{array}$ & $\begin{array}{l}\text { Child care system, care leave regulations, } \\
\text { institutional child care provision }\end{array}$ \\
& $\begin{array}{l}\text { Organization of } \\
\text { elderly care }\end{array}$ & $\begin{array}{l}\text { Elderly care system, legal obligations, } \\
\text { institutional care }\end{array}$ \\
Living arrangement & Co-residence & -> Housing \\
\hline
\end{tabular}

\subsection{The socio-economic situation and context}

The GGS covers the socio-economic situation of the respondent and the household regarding (1) jobs and labor income, (2) non-labor incomes (benefits and transfers), (3) wealth and (4) some selected expenditures on care and household services. Extensive attention is given to both the respondents and his or her partners' paid work if economically active: job position, type and sector of employment, size of company, public/private etc. Regarding the job relation, we can further distinguish its (1) legal dimension (employed, freelance, self-employed etc.), its (2) time dimension: working hours, time arrangement and flexibility including questions on the compatibility with family life and (3) the income dimension: salaries and benefits.

\begin{tabular}{lll}
\hline & $\begin{array}{l}\text { Individual economic well- } \\
\text { being }\end{array}$ & Macro context \\
\hline General & General wellbeing & $\begin{array}{l}\text { General level of economic development } \\
\text { (GDP etc.), price stability and } \\
\text { distribution of income and wealth }\end{array}$ \\
& Labor market \& employment system \\
Income & Work income & Tax benefit system, welfare state \\
& Transfers and benefits & $\begin{array}{l}\text { Housing market: prices and market } \\
\text { segregation; ownership vs. private and } \\
\text { public rental market }\end{array}$ \\
\hline
\end{tabular}

\subsection{Values}

The GGS includes a section on attitudes and value-orientations on gender and intergenerational relations as well as religiousness. This individual level data is placed within the context of the cultural, political and religious heritage of a country or region and the relative strength of confessions and political orientations. 


\subsection{The 16 contextual domains}

Following and summarizing the analysis above, we can identify 16 key contextual domains:

\begin{tabular}{ll} 
General demographic indicators & The tax benefit system \\
General economic indicators & Housing market and housing policy \\
$\begin{array}{l}\text { Labor market and employment } \\
\text { regulations }\end{array}$ & $\begin{array}{l}\text { Legal regulations of personal relations } \\
\text { and family responsibilities }\end{array}$ \\
Pension System & Education system \\
Parental leave institutions & Health \\
Childcare policies and institutions & Elderly care \\
Military and alternative civilian service & Political system \\
Unemployment & Culture \\
\hline
\end{tabular}

\section{The data content of the CDB}

\subsection{The behavioral and relational focus of the data collection}

While the general focus of the GGP and the important links of micro behaviors to the macro context are already reflected in the choice of the 16 contextual domains, the selection of variables within this broad range of contextual domains also has to consider the key behaviors and relations that constitute the dependent variables of the GGP. A guiding question for the decision to include a variable in the database or not therefore is if there exists a hypothesis that links this variable to one or more of the studied behaviors. We aim at identifying the variables that impact the timing, sequencing and synchronization of one or more central life-course events of the GGP.

Besides its focus on life course events, the GGP studies the respondent's partnership and intergenerational family relations. The GGP collects data on gender and generational relations in various dimensions, including their legal nature, co-residence, intensity, satisfaction, quality, power and decision making and economic interchange both regarding money and household production of child and elderly care. While the legal regulations of personal relations constitute one of the 16 contextual domains by itself, intergenerational and gender relations are of importance also as general focus of the contextual data collection. 


\subsection{The link between contextual and individual data}

With a view to support a multilevel approach to GGP data, we have to ensure that it is possible to link individual level data to their relevant context. Together with the innovative design of the Generations and Gender Survey, and especially its combination of retrospective and prospective components, this places high demands on our contextual data collection. In order to meet the historical depth of the Generations and Gender Survey and to link individual biographies to the historic context, we need to provide time series (or context history) data. As individual migration histories are not collected in the GGP survey (at least in the first two waves), this part of the data collection is limited to national level data only. The existence of essential variation over time is a key criterion for the inclusion of a time-series variable in the database. Time series and context history data will be collected for the time period 1970 onwards.

A link by region can be established for cross-sectional data and concerning the prospective component of the survey. Around $25 \%$ of variables of the contextual database are collected on the regional level - usually provinces - and will be updated with the successive waves of the survey. Considerable regional variation - which is a criterion for inclusion in the database - can frequently be observed for (1) economic indicators such as (un)employment, income, poverty and the housing situation; (2) general demographic indicators; (3) the availability and use of formal child-care institutions; (5) education; (6) dominant political tendencies as well as (7) the religious and ethnical composition of the population.

Besides the general link of individuals to context by time and region, different population groups find themselves in very specific contexts. Typical population groups frequently separated in aggregated statistics are constructed by gender, age group, marital status, educational attainment, and occupation. Additional groups that are relevant for the study of gender relations and frequently used in the contextual database are parents and mothers (e.g., the employment of mothers by age of youngest child). In order to determine policy contexts for individuals of different characteristics, the description of policy measures especially emphasizes the concepts of eligibility.

\subsection{Types of context data and data dimensions}

\subsubsection{Norms}

Important conceptualizations of norms useful for our purpose are (1) the statistical conceptualization of norms originating in behaviorism and the (2) sociological conceptualization of norms as social facts.

Statistical norms refer to regular behavior; a behavioral pattern becomes a norm if the majority of actors behave according to this pattern. Thus, norms are objectively observable 
and measurable e.g., by mean values, such as the mean age at first birth. In difference to this descriptive concept of norms, the second concept is prescriptive and value-oriented. In the sociological conceptualization of norms, norms are social facts that can be identified through the existence of certain sanctions rather than directly. In Parson's theory (1964), norms represent institutionalized role expectations. The objective character of norms is obtained by the integration of role expectations into the cultural system, formal and informal regulations and legislation; they obtain a regulating function due to different mechanisms of social control.

In the contextual database we include statistical norms in the form of mean values and age distributions of the key demographic events, such as the mean age at childbearing and marriage. Many of these statistical norms are found in the first contextual domain of "general demographic indicators" but are also present in most other contextual domains. As statistical norms change over time, they can also serve as indicators of developmental stages assuming universal transition mechanisms as in demographic transition theory. In this sense, statistical norms can be used as indicators of the prevalence or emergence of certain behaviors (e.g., unmarried cohabitation).

Statistical norms are "analytical variables" derived by aggregation describing means and distributions of individual events and characteristics. Statistical norms are also present in the context of policies, where they constitute important outcome variables, e.g., measuring enrolment and take-up rates. Besides the concepts of time (e.g., average age) and enrolment rates, some important statistical norms also refer to monetary concepts, such as a certain level of income or economic living conditions, seen as prerequisite for marriage and childbearing.

Legal norms and regulations are prescriptive and can be identified through the existence of legal sanctions for their enforcement. Many legal regulations impose important timing norms that impact key domains of the individual life course. This is especially visible for education systems that e.g., define the minimum compulsory time of schooling. Important timing norms are also set by work time regulations, paid maternity leave periods, the conscription age and time of obligatory military services or the legal retirement age.

Some legal norms impose important quality standards, e.g., staff requirements of childcare institutions, which may impact individual decisions on the organization of care.

Legal regulations also define family responsibilities and may restrict, prohibit or regulate certain behaviors and personal relations; examples being abortion laws, divorce regulations and the legal treatment of same-sex partnerships. According to their importance, these regulations constitute a contextual domain of the database of their own. 


\subsubsection{Policies and the welfare state}

Policy data constitute one of the core elements of the contextual database of the Generations and Gender Program. We are interested if, how, and to which extent public policies influence individual behavior and aim at providing instruments for policy-relevant research. Policies can be analyzed on several dimensions and at different levels. Bahle \& Maucher (1998) distinguish between six different approaches, some of which can directly be related to various streams of welfare state research:

(1) The study of social values and normative concepts, i.e., the principles underlying governmental action. Normative concepts are e.g., reflected in the different programs and priorities of political parties and also correspond to the various typologies of welfare state regimes, such as Esping-Andersen's classification of liberal vs. universal and conservative welfare states. Many useful classification schemes for policies and system designs are derived from this perspective and are useful to characterize the policies and welfare state institutions that are covered by our database. The dimensions used in the Contextual Database in order to either classify policies directly or by providing variables that allow such a classification include:

- general typologies for social security systems

- the underlying and supported family paradigm of male breadwinner vs. dual care and earner families; and

- the target unit of policies, distinguishing individualistic vs. family-oriented concepts.

(2) The study of political actors and programs. The development of welfare states involves and reflects the efforts and struggles of competing interest groups to gain political influence and to lobby policy makers to their course. The presence and power of certain groups reflect dominant value systems and - assuming universal movements such as secularization or female emancipation - to some degree the developmental stages of societies. The study of political debates reveals politically important and controversial topics and the extent of interest group mobilization. The contextual database includes information on the main political parties, their relative political strength as well as participation in government coalitions, as very often it is consensual politics that shape certain policies. Other variables include the religious composition of the population and the importance of churches and religious parties to society.

(3) The study of the administrative organization and implementation of policies. The level of policy implementation, i.e., the level to which policies are institutionalized on the level of central government or at the regional level may indicate national priorities and the extent to which policies are perceived as social rights rather than supplementary poor-relief measures, which are frequently organized at the local level. The autonomy of agencies from government is another dimension, and this autonomy is reflected in funding mechanisms. Especially government pressure to cut tax-financed programs may be greater 
if the social security institution or fund is government-funded rather than self-sponsored. Another dimension is the degree of administrative centralization or de-centralization of agencies and their clientele; the latter often applies to occupational social insurers. As to the contextual database, we are largely limited to national policies and capture the administrative organization of policies in an indirect manner, e.g., by indicating the coverage of programs (indicating the degree to which a given systems is universal).

(4) The study of single policy measures includes benefits, service provision and institutional regulations such as entitlement conditions, benefit rates and access to these services. This approach aims at developing a standardized description and quantification of key features of single or comparable policy measures. It is one of the challenges of comparative research to find such schemes that capture all important dimensions of policies and suit a wide set of possible policy designs. Applied to the contextual database, we follow this approach for various policies, most importantly parental leave institutions and childcare provision. Some of the main policy dimensions that we aim at capturing will be described below.

(5) Funding and social expenditure. This approach uses social expenditure as a measure of the welfare state at various detail levels. While the general level of social expenditure gives some indication of the extent to which a state engages in the provision of economic and social security etc., the study of how spending is distributed between different categories provides additional information. We can distinguish between two important perspectives. The functional perspective focuses on the purpose of social spending, i.e., to which extent provisions are allocated to certain means and population groups, e.g., old age, health, unemployment, family, survivors, disability, existence minimum. Expenditure data by population group reveals important Generations and Gender paradigms governing welfare-state policies as it highlights priorities in the distribution of welfare state provisions and recipients: young versus old, families versus individuals, men versus women, mothers versus fathers, care receivers versus care givers etc.

The second perspective is an institutional one and involves an analysis of who provides which kind of benefit. This approach is linked to the study of administrative organization as described above, quantifying the share of spending channeled through the different agencies. This approach reveals important aspects of the underlying mechanisms, principles and paradigms of welfare state regimes. As different institutions are based on different funding mechanisms, e.g., general taxes or individual social security contributions, this perspective also captures some aspects of the funding mechanism and its relative importance to the tax/benefit and social security system. The institutional perspective also includes an analysis of the share of expenditure by the level at which programs are implemented, i.e. the national vs. regional. To some extent this level indicates the perception of provisions as social rights. 
(6) The study of policy impact. This approach focuses on the outcome of policies. Thereby we can make a distinction between the theoretical study of policy impact e.g., by means of model calculations and the microsimulation of tax-benefit systems and empirical research. Examples of the former are the OECD "Taxing Wages Database", which provides internationally comparative data on direct tax collected from employees and their employers. From such calculations we obtain important indicators of the "pressure on behavior" of tax-benefit systems, such as marginal tax rates and the tax treatment of spouses and children that influences female labor-market behavior especially. The contextual database contains a limited set of such variables. The provision of instruments for the empirical study of the impact of policies on demographic behavior and gender and generational relations is one of the main aims of the Generations and Gender Program.

What are the key dimensions of policies we aim at measuring? Measurement dimensions have a close link to social norms and values. The welfare state itself evolved from the recognition of social rights as a central value that a state is obliged to guarantee e.g., by applying social policies. Welfare state research has identified various typologies of welfare state regimes, which correspond to different priorities and alternative solutions of value conflicts. The most important values around which various measurement dimensions can be clustered relate to the concepts of agency, equality, security and rights (Neyer 2002).

(A) Social Rights: To what extent does a state consider material and social needs to be economic and social rights, and what steps does it take to guarantee these rights? The term "welfare state" is closely linked to Marshall's (1950) concept of social citizenship based on the recognition of social rights. An influential way of specifying social citizen rights is linked to Esping-Andersen's concept of de-commodification: the degree of the weakening of the cash-nexus by granting entitlements independent of market participation ${ }^{4}$ (Esping Andersen 1999). The degree to which policies and social security systems are designed in recognition of social and economic rights is reflected in legal entitlements, eligibility, coverage, the linkage of benefits to individual contributions and the existence and level of minimum standards, e.g., minimum benefits or the quality standards of services. Some inference can also be drawn from the degree of public sector involvement in the provision of services.

(B) Equality: To what extent does the state reduce social and economic inequalities? What is the extent of such inequalities? What are they based on: gender, ethnic group, age, class, occupational sector, educational attainment? The concepts of equality include (i) equality of life chances, i.e., the distribution of opportunities, resources and capabilities; (ii) the

\footnotetext{
${ }^{4}$ Prerequisites of this concept are commodified agents, i.e., agents that are active in the labor market; this makes the concept unacceptable from a feminist perspective, leading to various attempts to reformulate the concept in order to account for the gender dimension.
} 
cross-sectional differentiation of living conditions; and (iii) permanent social cleavages, i.e., class formation and the intergenerational transmission of life chances (EspingAndersen 1999). Equality concepts need to be contrasted by the concept of equity, the latter which refers to fairness and justice. Equality has important gender, generational and class dimensions. Measures of the extent of equality are participation and enrolment rates (e.g., labor-market participation by sex and age) and distributions of e.g., income. Policy dimensions reflecting equality concepts include benefit eligibility and coverage, public sector involvement in service provision (e.g., schools), the existence and mechanisms of measures to provide access to services and markets (e.g., housing, education), the (equal?) treatment of unmarried and same-sex partnerships, the special protection of institutions, such as the family, and affirmative actions to actively promote equality.

(C) Risks: This concept has to do with the likeliness of unfavorable events, such as unemployment and sickness, the consequences of such events, such as poverty and dependence, how these risks and consequences are related to the life-course events and relations studied in GGP, and the ways in which the state impacts these risks and consequences. Risks directly addressed in the database are poverty and unemployment (by age, sex, family form and other characteristics). Important policy dimensions are replacement rates including the underlying concept (e.g., poverty prevention vs. status maintenance), durations (of benefits; average durations of unemployment) and the treatment of unpaid care work by the pension system.

(D) Agency: To what extent does the state enable a person to enter into or exit from social and economic relationships? Agency refers to a set of choices, the ability to choose and to the incentive system that influences the choice (to be) made, including the individual's bargaining position within the family. The concept of agency is frequently combined with the concept of equality in terms of 'equality in the freedom to achieve'. The concept of agency is especially useful for the study of gender differentials ${ }^{5}$. Policies interfere with agency in various ways. Policies impact the economic burden associated with behaviors studied in GGP: rent or mortgage repayments, school fees, the cost of care services etc. The availability and opening hours of care and educational institutions impact the time commitment associated with family responsibilities and - together with affordability - the reconciliation of family and work. The set of choices is also influenced by the flexibility of policies (e.g., the deferability of parts of leave periods). An important component of agency refers to the incentive system. Especially the organization of paid and unpaid work between partners - including the decision of who takes up leave periods - is influenced by the tax and benefit system. Agency is also effected by legal regulations and restrictions.

\footnotetext{
5 The term "gendered agency inequality" (quotation marks) was introduced by Korpi (2000)
} 


\subsubsection{The general living standard and economic situation}

Beside norms, legal regulations and policies, we can expect the general living standard and economic situation of a country or region to effect life course decisions as well as intergenerational and gender relations. Measurement dimensions are the general level (income, GDP), participation in economic activity, income distribution, economic stability (inflation) and economic growth.

\subsubsection{Culture}

Concerning the cultural context, the contextual database gives information on the regional population composition by religious affiliation, language and ethnical group.

The following illustration summarizes the key concepts that the database variables should relate to - the focus - and the variables that should be included - the coverage. These concepts also lend themselves as classification scheme of the database.

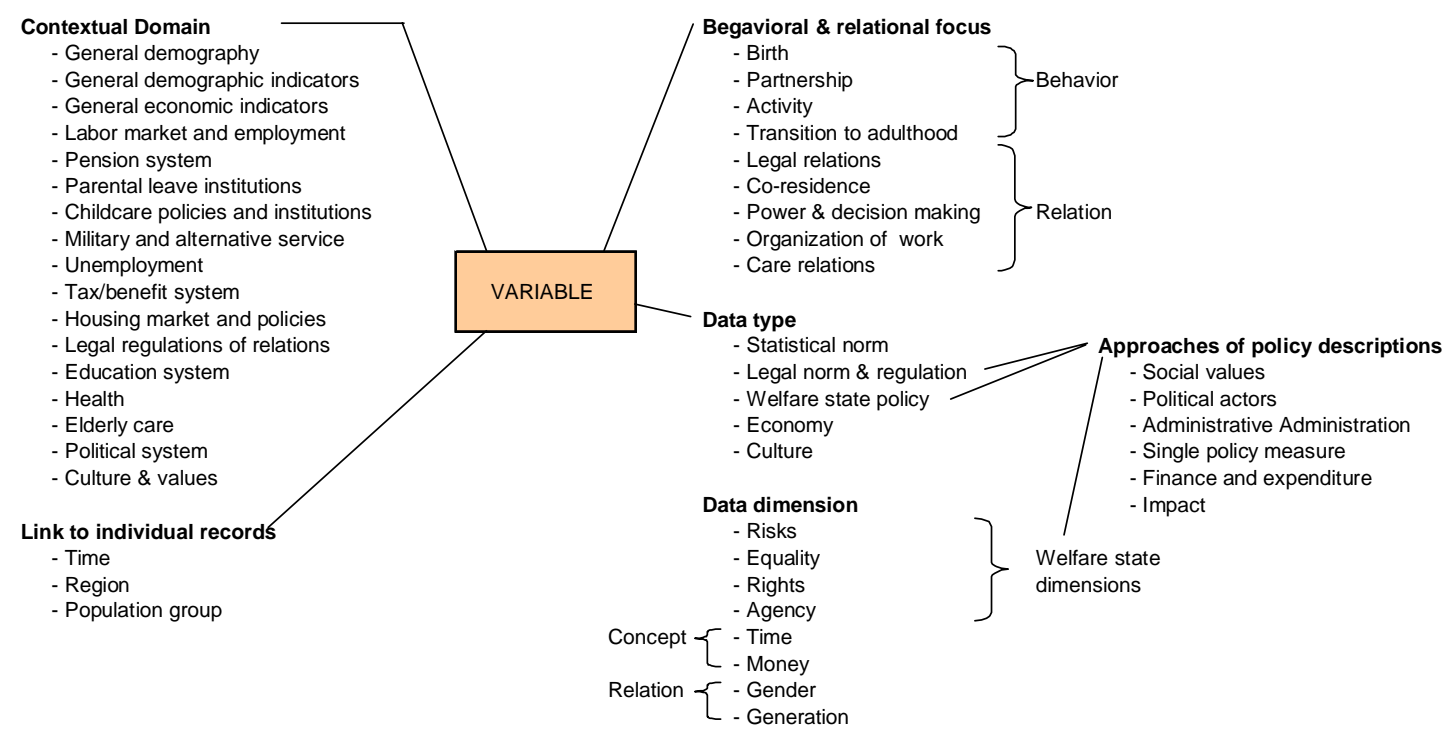

Illustration: Key concepts and variable classification

\section{Contextual domains}

In the following, we describe the general focus and coverage of the contextual database by contextual domain, each section followed by an overview of the concrete Bulgarian context. A list of all variables ordered by contextual domain is contained in the Appendix. 


\subsection{General demographic indicators}

This database section consists of a brief selection of key demographic indicators. The behavioral focus lies on the classic demographic events of birth, marriage, divorce, migration and mortality; additional topics are abortion and single motherhood. Most variables are analytical variables derived by aggregation describing means and distributions of individual events and characteristics. As part of the contextual database they can serve as indicators of (statistical) age norms (e.g., mean ages for events such as marriage and first birth) or statistical norms in terms of the prevalence of certain behaviors (e.g., marriage, divorce, abortion, migration). Most of the variables are collected on the national level in the form of time series starting 1970 and onwards, and on the regional level in order to capture important regional variations and very recent trends since 2000. The dominant measurement dimension is related to time in the form of individual age, e.g., the mean ages at demographic events and age distributions. Some of the variables, such as divorce rates, also relate to concepts of risks, divorce, single motherhood, illegitimate births, and abortions can also be related to the concept of agency.

\subsubsection{The demographic situation of Bulgaria}

Bulgaria is one of the countries in Central and Eastern Europe with the most clearly noticeable demographic decline. This trend has been a long-term one. However, only in recent years have its negative features become manifest in the basic demographic processes.

The country's population has substantially decreased as a result of demographic developments and emigration. According to statistics provided by a census in 1975, the population totaled 8727771 in that year to experience decline to 8487317 in 1992 and to 7932984 in 2001. Two years later, the population saw another decrease to 7801273 at the end of 2003.

An increase in the death rate and a drop in the birth rate were the main characteristics of the 1970s and the 1980s in terms of demographic trends. In the late 1980s, the country came close to the point at which the birth rate and the death rate became almost equal. As early as in 1990, the death rate exceeded the birth rate by 4000 people and the country reached a state of depopulation. In 2001, this imbalance reached 45000 compared to 50000 and 45000 in 2002 and 2003 respectively.

In view of these critical conditions, the institution of marriage has become an object of special concern to society.

Both the absolute and the relative drop in the marriage rate began in the late 1970s. Whereas in the 1970s, there were 70000 marriages a year, in 1990 the number dropped to 60000 and in 2000 to 35000; this compares to 30000 in 2003. 
Bulgaria is one of the European countries where early marriage is common. The average female age at first marriage was 22 years between 1970 and 1994, but during more recent years this figure has increased to 24 - 25 years.

During the past three decades, there has been a stable and relatively low rate of divorce in Bulgaria, namely $1-1.5$ per thousand. In terms of divorce rates, the country thus comes close to most of the countries of Southern Europe, where the family as an institution has been relatively stable.

Depopulation in Bulgaria is at times higher in villages than in cities. It began in villages as early as in the mid-1970s. In towns and cities, depopulation became a fact in 1994. These differences can be explained by the predominance of aged people in villages. The birth rate is lower there, while the death rate is twice as high as in urban centers.

In 2003 all regions of the country were in a state of depopulation: varying from 3.9 per thousand in the South-East region to 11.3 in the North-West region. Besides the NorthWest, the North Central region sees depopulation above the country's average (8.7).

Demographic, socio-economic, socio-psychological and other factors influence the formation of reproductive behavior in the country. The two-child model, which was a characteristic feature in the 1970s and the first half of the 1980s, rapidly became a thing of the past: The total fertility rate in 2003 was 1.23 and the net coefficient of reproduction amounted to 0.58 .

Emigration has a very essential and direct impact on the population and the labor force. It has been one of the main factors behind the country's unprecedented "demographic collapse". The majority of the emigrant population is aged $20-35$ years, resulting in great loss of human capital, bearing in mind that people with higher education and qualification emigrated.

According to the last census (of 2001), the number of emigrants during the $1985-2001$ period totaled 679141 .

\subsection{General economic indicators}

This database section consists of a very brief selection of general economic indicators that are not directly linked to specific activity statuses (employment, retirement, unemployment etc.) or policies and that are therefore not included in the various other contextual domains. General economic indicators, such as the level of economic development, growth rates and the economic stability of a country or region, impact most behaviors studied in our program. The behavioral focus of this group of variables is accordingly broad.

Economic indicators typically relate to the concept of money. A first group of variables consists of general measures of economic output and prices, and their development over time - information that can be used to identify periods of economic growth or crisis and instability (inflation). These data are national level time-series. A second group of 
variables concerns household income distributions and poverty, capturing some aspects of the economic risks of certain population groups on the regional level.

\subsubsection{The Bulgarian Economy}

The political and historical peculiarities of Bulgaria's development have invariably determined the development of its industry, and the creation and development of its cities and industrial areas. During the planned economy period (1946-1989), there were significant changes in the development and organization of its industry, the size of enterprises, their number and the sectorial structure. The process of industrialization had a major impact on the transformation of the rural network and the formation and development of industrial regions. The main characteristics of the Bulgarian economy during the period before 1989 were:

- Exceptionally large-scale industrialization, with a very high share of big industrial plants (employing thousands of people).

- The predominant development of heavy and strongly material-dependent industry with limited national energy, ore and chemical materials necessitated the import of these materials mainly from the former USSR.

- The dependence of the national economy on Comecon (the country's foreign trade within Comecon was $77 \%$ in 1985).

- According to the official macroeconomic indicators, unemployment did not exist during the pre-transitional period.

Transition to the market economy after 1989 was hindered by delays and errors in promoting reforms and the lack of a precise strategy and corresponding policy of economic development. The basic macroeconomic indicators that characterized the state and trends in the development of the Bulgarian economy in the 1990s have shown a serious slump in real GDP values irrespective of the positive fluctuations during certain periods. However, since the year 2000, a slow increase in GDP has been observed. Following a deep economic crisis in 1996/1997, which affected all spheres of social life, Bulgaria launched in July 1997 a stabilization program. Fundamental to this program was the introduction of a currency board arrangement (in order to prevent rising inflation) and the stimulation of privatization and banking sector recovery as well as a tax reform and several other macroeconomic measures.

The key characteristics of the economic transition in Bulgaria are:

- A considerable decline in economic activity - at the bottom of the economic crisis in 1997, the Bulgarian GDP fell to $63 \%$ of its level in 1989 and in 2002 it was still under the 1989 level $(93 \%)$.

- The introduction of a currency board in 1997, which is still functioning. 
- The privatization of state-owned assets started in 1993 but progressed slowly (a mere $7 \%$ of state-owned assets were in private hands in 1997). After the economic crisis, the process accelerated and $82.33 \%$ of all assets, excluding the infrastructure, were privatized by September 2003. As a consequence, the share of the private sector in the gross value added increased to $72.7 \%$ of the GDP.

- Unemployment started rising with the beginning of the reforms in 1991 and reached its highest level (18.1\%) in 2000.

- Low wages, low pension levels and a high level of unemployment resulted in a large number of people living below the poverty line.

Poverty is considered one of the main social problems in the country. Social policy in Bulgaria after 1990 has been fully directed at the implementation of programs of social assistance and benefits for the poor. Between 1995 and 2004, four national representative surveys on poverty $(1995,1997,2001$, and 2003) were conducted with the financial help of the World Bank. The latest survey, "Multipurpose monitoring of households in Bulgaria", was held in 2003 by the National Statistical Institute. Preliminary data were presented at the national conference in Sofia, July 2004, with a publication of this presentation forthcoming by the end of 2004. According to these data, the line of poverty is defined at the level of 102 BGN (61Euro). The number of poor households amounts to 409000, constituting 1113000 people. Of these, 61\% live in cities and 39\% in villages. Households with three and more children are more prone to poverty; particularly $22 \%$ of children aged $0-3,20 \%$ of children aged $4-7$ and $22 \%$ aged $8-14$ are considered to be poor. Ethnicity is one of the main differentials of poverty. Of the Roma households, $64 \%$ are defined as poor compared to $23 \%$ of poor households among ethnic Turks and $9 \%$ among ethnic Bulgarians. The share of elderly poor is $11 \%$ as to retired people living in a two-member household (retired spouses), while it is much higher for retired lone men and women (onemember household) $-17 \%$. Of all people aged $65+, 65 \%$ are considered to be poor. The poverty profiles according to economic status have the following distribution: $24 \%$ of the economically inactive people (long-term unemployed and pensioners) are poor, $29 \%$ of the unemployed (short-term and non-registered unemployed) and $8 \%$ of the economically active are poor. Low wages and salaries that are below the level of subsistence place those affected into the category of "poor working people", and this applies to a relatively large part of the population. Lone parents also come under the main risk groups of poverty $26 \%$ of lone mothers and $29 \%$ of lone fathers are defined as poor. The survey data provide additional information on poverty profiles according to gender, professional status, ruralurban dimension, regional levels, etc.

\subsection{Labor market and employment regulations}

Labor market characteristics and employment regulations are of key importance in the study of activity careers and their interaction with other life course domains. They impact many aspects of family and gender relations studied in the GGS. Career chances on the 
labor market have an influence on the transition to adulthood as well as on retirement decisions. In modern societies, the major socioeconomic stratification processes take place in the labor market. Labor-market participation, besides its importance to generate personal and household income, is also likely to "affect a person's self-perception, identity, and effective scope in ways that may influence capabilities and freedom in many different areas of life [..] and [they are] likely to affect interaction patterns and bargaining positions within the family" (Korpi 2000, p139).

The variables of this section cover both concepts of time, e.g., in the form of work-time regulations and regulations concerning and promoting part-time work, and concepts of money, i.e., income from employment. Not surprisingly, many concepts developed by welfare state researchers are linked to labor, most prominently Esping-Andersen's concept of de-commodification. Individual agency is clearly influenced by chances on the labor market and by regulations that may influence the reconciliation of work with family obligations. Labor market policies also impact the generational distribution of risks. A high level of protection of people in the labor market may create an insider-outsider problem, directing labor market risks towards the young who as a result may have difficulties to find stable employment. Being the main source of income, data on wages by sex and age reveal useful information on cross-sectional, generational and gender equality.

The variables in the contextual database can be divided into various groups. We first study labor-market participation - outcome variables that may constitute statistical norms - by age, sex and family status (mothers by the age of the youngest child). These variables capture important equality aspects, which are complemented by general variables on the labor market, such as sectoral and public employment. Monetary equality aspects are captured by a set of variables on wages and wage distributions. Another group of variables focuses on employment stability and risks, measured by the permanence of job contracts and labor turnover. An important set of variables connected with the concepts of agency and reconciliation of work and family obligations concerns work time regulations, such as working hours, holidays and part-time employment. Regarding the latter, we include policy information on the promotion of part-time work, legal entitlement to part-time work and outcome variables on part-time employment, e.g., of mothers by the age of the youngest child. Another aspect of labor market flexibility linked to time is connected to standard hours, extra compensation for work during non-standard hours and measures to reduce work during non-standard hours, e.g. shop opening hours.

\subsubsection{Labor and employment in Bulgaria}

Bulgaria's population participation rates in the labor market were relatively high over the period 1970-2003, both for men and women. Their levels were comparable with those for the North-European countries over the period 1970-1989. By the end of the 1990s, the participation rates had fallen significantly. They have been rising again since 2001 . 
The total number of actives in the Bulgarian labor market decreased over the whole period of research. By 1985, it had increased, although slowly, from 4.2 million in 1970 to 4.7 million in 1985, and in the remaining two decades of the period it dropped steeply (to 3.3 million in 2003). The development of employment in the first sub-period was conditioned mostly by the slight increase in the size of the working-age population, by retention at the same level of inactivity, which was due to invalidity and other reasons to do with unhealthy situation among the working-age population, by the rising employment level of people out of working age, especially of the over working-age population, as well as the rising employment rates among the female population. The tendencies related to the decrease in the second sub-period of those active in the labor market can be attributed predominantly to changes in the country's economic system and transformations in the economy's organization.

The characteristics of the active population ${ }^{6}$ have been changing significantly since the 1970s. The sex distribution of this population is the only one of the characteristics that did not change much throughout the studied period. Men's preponderance in the labor market was stable throughout the whole period, although this preponderance was higher at the beginning of the period and diminished only slightly by the end of the period. These changes were due to the rapid increase in the number of women who entered employment by the end of the 1980s. This tendency combined with the steeper decrease in the employment level of men and with emigration gender effects (in the beginning of the 1990s at least, when an increasing number of men at working age emigrated) during the next decade of the studied period to form the current sex distribution of active population.

The main changes in age distribution concerned, first, the decrease, both absolute and relative, in the young labor force over the observed period. One of the basic reasons behind this trend is a long-term fertility decline in the country, free secondary (and higher) education, the statistical practice of deducting the number of men in temporary military service from official total employment statistics by the mid-90s, and changed labor demand parameters over the transition period. However, intensifying population and laborforce ageing processes led to labor force deficits by the end of the 1980s and thus to fluctuating levels in the percentage of people over working age. Since 1990, the percentage of people over working age in the actives' age distribution has gradually fallen to negligible values, mainly because of very high unemployment.

The urban actives total increased slightly (by 1.4 times) over the 1970-2003 period, while the rural actives total decreased steadily (it was almost 3 times lower in 2003 than in 1970). The last 20 years of the period showed an absolute and relative decrease of actives not only in the villages where this process started as early as in the mid-50s and has not ended ever since. A process of actives total absolute decrease was observed for the first

\footnotetext{
${ }^{6}$ The term "active population" is used by the NSI to denote the total of the employed and unemployed at a definite moment.
} 
time in the towns in the late 1980s and has been continuing since. These long-term trends resulted in about $3 / 4^{\text {th }}$ of actives living in towns by the end of the period under study.

The sectoral distribution of actives has been undergoing very significant changes since 1970. At the beginning of the period, almost half of the actives were employed in the primary sector (44\%), whereas in 2003 the percentage of those employed in the tertiary sector was the highest (58\%) of all employed. Considerable changes in the country's economic structure over the observed period determined these relatively fast and stable processes of employed redistribution. Some of these changes are connected to industrialization and the development of a number of industrial branches by the early 1980s. Others are related to the rapid development of the tertiary sector, which started in the late 60s and largely accelerated in the early 1990s.

In 1970 the employed total was made up almost equally between the state and the cooperative $^{7}$ sectors of the economy (with an insignificant preponderance of the former). By the beginning of the 1990s, the public sector had become predominant ( $82 \%$ of the actives' total in 1992), the co-operative sector's percentage had suffered a reduction (6\%), and the percentage of those employed in the private sector had risen slightly $(11 \%)$. In 2003 , the latter figure rose to over $62 \%$ in contrast to the respective indicator for the public sector $(37 \%)$, and the percentage of the co-operative sector fell under $1 \%$.

A stable tendency of actives' average educational level rising was observed for the period under study. The percentage of actives with low education levels (primary or lower) fell rapidly and steadily since the mid-60s to about 1/4th of the actives' total in 2003. The percentage of actives with secondary education rose almost fourfold during this period and in 2003 this group prevailed over the others (55\% of the actives' total). A stable tendency of increase of the percentage of highly educated actives was observed over the entire period. Their percentage reached 1/4th of the actives' total at the end of the period, thus exceeding for the first time (in 2001) the lowly-educated actives group, although very slightly.

\subsection{Pension System}

Pension systems historically belong to the oldest social security institutions, initially thought as insurance against reduced working ability at high age and conceptually closely linked to health insurance systems. With the introduction of a legal retirement age independent of health status (very often combined with an early retirement age for health reasons), pension systems created new age norms for the transition to "the third age".

In the context of the Generations and Gender Program, we are both interested in the current socio-economic circumstances of retired people and those close to retirement (the GGS

\footnotetext{
${ }^{7}$ The co-operative sector included corporations of private companies (mainly small farms and small enterprises).
} 
collects detailed information on retirement intentions), and also in the way in which the pension systems may impact behaviors at much younger ages, such as labor- market participation and the take-up of leave periods. Pension systems do not only have an important inter-generational dimension, sometimes characterized as generation contract, but are also highly gendered systems. Eligibility for public pensions and the calculation of pension benefits is usually dependent on contribution histories and therefore on labormarket participation and income - and very different regulations e.g., for dependent spouses or how (and if) unpaid care work is accounted for. While gender inequalities in material terms disappeared in partnerships (Korpi 2000), gender agency inequality (e.g., in the distribution of paid and unpaid work) persist and often become manifest in material terms in case of partnership dissolution: lone mothers, widows and divorced women are at higher risk of poverty in most societies - before and after retirement.

\subsubsection{The Bulgarian pension system}

Many changes to legal pension regulations had been introduced in Bulgaria over the period under study. Compulsory pension insurance covers three main groups of pensions, namely (1) pensions concerning employment duration and retirement age, (2) disability pensions (as a consequence of general disease or an accident at work or a "professional disease"), and (3) non-activity related pensions, such as military disability pensions, civil disability pensions, social pensions, social disability pensions, special merit pensions, and personal pensions. In 2001, the option to take up additional pension insurance was introduced.

Activity-related pensions (95.7\%) predominated in 1989 as to pensioners' distribution by type of pension. They rose very slightly to $96.3 \%$ in 2003 . The total of pensioners receiving non-activity-related pensions increased in absolute terms (by 5000), too, but in relative terms the percentage remained at about $2.8 \%$ in 2003. The third pensioners' group total has been decreasing both in absolute and relative terms since 1989 (by 15000 in 2003 compared to 1989 and from $1.5 \%$ to $0.8 \%$ respectively for the same period).

The pensions' total dynamics followed very closely the development of the pensioners' total. The total figure of pensions reached 2340000 in 2003, which means that about 340 000 people had more than one pension. The majority of them $(88 \%)$ received an additional social disability pension.

The distribution of pensions by type of pensions was close to that of pensioners, too. The main differences between the two concerns, on the one hand, a slightly lower percentage of activity-related pensions in 1989 (92.3\%) and its continual decrease (it dropped to 84\% in 2003). This trend reflects the influence of rapid and significant population ageing, and of changes in insurance coverage, in the legal retirement age and entitlement to the number of pensions. On the other hand, there was a considerable leap in the percentage of nonactivity-related pensions in 2001 and its follow-up rapid rising. Its value grew from 5\% in 1989 to $10.3 \%$ in 2001 and in 2003 it reached $14.6 \%$. The tendency was connected to changes in the Social Insurance Code, which provided invalids of the first and second 
disability groups (with more than a decrease by $71 \%$ in working capacity) with entitlement to an additional social disability pension.

The development in the average level of pensions showed a significant rise by the end of the 1980s (by more than 1/3rd in comparison to its reference level in 1970). A considerable drop in its level occurred afterwards due to the indexation and compensation of pensioners' income regulations in the background of high inflation rates over the transition period to a market economy. The growth in the level of pensions fell behind wage developments in the last twenty years. In 1984, the average monthly pension was $42.5 \%$ of the average monthly wage; in 1997 it was only $28.2 \%$. Its level rose to $39 \%$ in 2003, however. In the same year, $23.9 \%$ of pensioners received a minimal pension and $7 \%$ of the total figure received the maximal one.

The development in the average duration of pension received shows an increasing tendency over the period under study. The total indicator increased from 16.0 years in 1989 to 18.7 years in 2003. This trend of average duration rising applies to the respective indicators by sex, too. The average duration of pension received rose from 13.7 years to 16.1 years for men and from 18.8 to 21.4 years for women over the same period.

Pension expenditure grew throughout the period in absolute terms. The percentage of this expenditure in relation to GDP varied during the 1983-2003 period between 6.1\% (1997) and $10.9 \%$ (1993). The evolution to the latter was marked by a relatively steep growth in pension expenditure during the 1980s and early 1990s (from $7 \%$ in 1983 to $10.9 \%$ in 1993), with the main reasons being an acceleration in the process of population aging, the relatively low legal age of retirement (60 years for men and 55 for women) and an increase in the average amount of pensions received. Between 1992 and 1997, the percentage of pension expenditure in relation to GDP significantly dropped owing to a reduction in the average pension amount resulting from an economic crisis in the country. By 2003, the figure rose to $9.1 \%$, mainly as a consequence of new pension regulations concerning the legal retirement age, an increase in the average pension, and pension insurance coverage, etc.

\subsection{Parental leave institutions}

We use the term parental leave institutions to sum up maternity, paternity, parental and care leave systems, i.e., leave and benefits related to confinement and the possibility of parents to care for their children during the first months or few years after birth.

The first of the wide range of possible measures that was introduced in most countries as early as in the first half of the past century was maternity leave as part of the social insurance system for employed women. Recommendations for a minimum of 12 weeks maternity leave by the International Labor Organization (ILO) date back to 1919. In 1952, during a second convention, ILO suggested 14 weeks of maternity leave with full wage 
replacement, which became the minimum standard for maternity leave regulations for EU countries (supplemented by minimum standards for care leave periods).

Parental leave institutions set norms and create incentives regarding how care-work is organized between parents, and between parents and other formal or informal childcare providers and institutions. The combination of job protection periods and benefit schemes interact with the career and income risk of spending some time out of employment caring for a child and how care-work is shared between partners. Together with the availability, affordability and quality of childcare facilities, it influences the gendered agency of parents and has therefore a strong effect on the risks and consequences of parenthood.

Parental leave institutions are an examples of policies that comprise the whole variety of welfare state dimensions: income and job risks by temporarily leaving the labor market, gendered agency influenced by the flexibility of schemes and gendered incentives (who should take up leave), underlying equality concepts as well as rights, e.g., to return to a job after leave. Taking into account the assumed importance of leave policies, we aimed at developing a detailed comparative scheme of the measures that capture many important dimensions of policies and suit the wide set of policy designs found in different countries. To complement these policy descriptions, we also collect information on the policy outcome in form of take-up rates and times, and quantify the percentage of parents eligible to the benefits.

\subsubsection{Parental leave institutions in Bulgaria}

Leave due to pregnancy, childbearing, adoption and childcare is set out in the Labor Code and its regulations. Since the early 1970s until the end of the 1990s, leave duration owing to pregnancy and childbearing was defined by the parity of children - 120 days for the first child, 150 for the second, 180 for the third child and 120 for the fourth child and following. The leave was divided into 45 days before delivery and the reminder after delivery.

All mothers-to-be were entitled to leave, independent of the length of their activity in the labor market. Following expiration of childbearing leave, a woman was entitled to take paid childcare leave until the child reached 2 years of age (this regulation was valid for the first, second and third child) and 6 months for the fourth child or a child of the next parity.

A mother or woman who adopted a child received payment equal to the minimum wage. When a mother did not take leave and did not return to her job, she was entitled to receive $50 \%$ of the minimal salary (in addition to her usual wage). Paid childcare leave could be shared by the father or one of the grandparents if he/she was still in employment at the time of leave entitlement. If the grandparents were pensioners, they were not entitled to take leave. After the expiration of paid childcare leave, the mother (or father or one of the grandparents) was entitled to take one year of unpaid childcare leave under the same 
conditions as for paid leave. All of these leaves were considered as labor activity and are included in the length of years of employment needed for receiving a pension.

Some changes concerning childcare leave were adopted in the Labor Code in 2001. The total time for childbearing leave is 135 days, independent of the order of birth. Bulgarian law allows the mother to take 45 days of paid leave before the delivery and 42 days after the delivery for every birth. The mother can take maternity leave for 48 days for a liveborn child. The entire period for childbearing leave is compensated at 90 percent of the employee's mean earnings for the last six month period preceding the birth.

All women with social insurance giving birth are entitled to childcare leave of two years, for the first, second and third birth. The leave duration for higher-order births is reduced to 6 months. Childcare leave until the child reaches two years of age is compensated at the minimal salary in Bulgaria, which equaled 120 BGN (60 Euros) in 2004. If the mother works and chooses not to take advantage of this leave, the employer has to pay an additional $50 \%$ of the minimal salary on top of her salary (30 Euros). Childcare leaves till the second year of the child can be shared by the second parent or one of the grandparents if they are in employment and have social insurance.

Bulgarian law allows unpaid leave for bringing up a child from the second to the third completed year of a child. A new amendment was adopted in July 2004. It shortened unpaid parental leave to six months and the total period of leave that could be taken lasted until the seventh year of the child. The employer provides this leave with a job guarantee. In the private sector, where $70 \%$ of all people work (this percentage is much higher for people aged 20-39), most small enterprise employers usually are not inclined to hire pregnant women or women with small children. By the same token, they are not inclined to provide a job guarantee. It is up to the mother how long she wants to take unpaid leave, and the leave can be shared with her husband, too.

The state has been making considerable efforts in supporting non-working women who give birth and have no social insurance. Legislation on family benefits for children, adopted in 2002, allows for childcare leave of one year, with a sum of 100 BGN compensation (50 Euros) for women who are not employed. A mother who has no social insurance and whose child is disabled can receive a monthly compensation of 100 BGN (50 Euros) until the second year of the child.

According to the Social Insurance Code, leave for a sick child covers up to 60 days for each of the two consecutive years to which it applies. The leave can be shared by family members with social insurance.

The current package of family leave benefits in Bulgaria is designed to reduce job-related penalties of parenthood experienced by working mothers. 


\subsection{Childcare policies and institutions}

Together with care leave institutions, childcare policies strongly influence the choices that parents have in the organization of childcare. The need for childcare facilities in order to reconcile work with family life was also recognized by the European Union, which set "Barcelona Summit" targets for the availability of care institutions to $33 \%$ of children below 3 years and 90\% of children from age 3 to school age for 2010. Such recommendations and targets also effect the candidate countries to the EU, including Bulgaria, which traditionally has a very dense system of childcare services. Currently, enrollment rates in childcare facilities for children below age 3 vary between 3\% (Greece) and over 60\% (Denmark) in the EU15 countries, reflecting the large variety of how early age childcare is organized in different countries.

The organization of childcare is closely linked to welfare state regimes. The universalistic approach emphasizes the legal entitlement to fulltime care services that are usually provided by the state and fulfill high standards of quality, e.g., regarding training requirements of staff. Conservative states rather invest in generous leave systems that rely on the family (mostly women) as main care provider. A third type of policy mix consists of heavy public investments in both areas (cash support and childcare services) not aiming to create incentives towards certain types of the organization (and therefore possibly cementing existing patterns) of care but providing a broader range of options, or more "freedom of choice". On the other side of the possible spectrum are countries with very low levels of public investments in childcare, that may be distinguished from countries with high female labor-market participation and an emphasis on market solutions (the liberal welfare state regime) and countries with very low female labor-market participation with a strong reliance on families (i.e., women) as main care providers. Transition countries like Bulgaria which generally do not fit into the classic standard classifications of countries into welfare state regimes are particularly interesting cases for the analysis of individual behavior in a changing context.

The key dimensions of the analysis of childcare policies covered in the contextual database include the availability of care institutions of different types and costs, and how they are shared between parents and the public, the quality of childcare institutions, the existence of legal entitlements to institutional care, enrollment rates by age and institution type, and timing norms like (pre)school entry ages and typical school hours.

\subsubsection{Childcare in Bulgaria}

For the last 5 decades, a state run network of preschool child care institutions has been fully developed in Bulgaria. This network includes nurseries, kindergartens, residential institutions for children abandoned by state parental care (the so-called "mother and child" institution) and institutions for social care. 
Nurseries take in children aged 10 months to 3 years (and in exceptional cases babies as young as 2.5 months of age). They are educational institutions that accept children when the mother is working, studying or looking after sick or other children. Nurseries can be of the daily, weekly, seasonal and sanatorium type.

The "mother and child" institution is a specialized childcare institution for children in high risk groups (medical and social) up to the third year of the child's age. It also takes in pregnant unmarried women. Children of lone mothers, of deceased mothers, abandoned children and full orphans are eligible, too, to reside in these institutions. Children of mothers, who are hospitalized, imprisoned, as well as children of mothers and fathers suffering diseases that constitute a threat to the child's health are entitled to join these institutions.

Kindergartens and united childcare institutions (including nurseries and kindergartens) serve as units for social preschool training, the psychological, physical and social education of children and their successful preparation for school. Children aged 3-7 attend kindergarten either full time, part-time, or on a weekly or seasonal basis. The institution also serves as a sanatorium and a temporary home for disabled children. United childcare institutions take in children aged from 10 months to 7 years. Children of parents who are in employment, do military service, study, have a disability or stay in hospitals can attend kindergarten, too.

Kindergartens can be state, municipally or privately managed. The launch and functioning of preschool childcare institutions is regulated in the Law on Education, the Law on Health and numerous rules and regulations for their implementation.

Children begin school at the age of seven years completed during the year for enrollment in the first grade. Children aged 6 are also eligible to attend school when their parents attest that the child in question has achieved an appropriate level of psychological and physical development.

Over the period 1970-2003, a stable trend of a decrease in the number of nurseries and kindergartens as well as in the number of enrolled children has been observed: from 1003 nurseries in 1970 to 630 at present. Over the same period, the number of children has halved: from 44000 to 22000 . Kindergartens also have been reduced, from 5054 to 3278 . A decrease in the number children who attend kindergartens full-time has been noticed, too. The number of part-time and seasonal kindergartens attendees, however, has risen. As a result of these developments, the overall number of children enrolled in kindergartens remains at the level of 201100 children (2003).

The enrollment rate of children in kindergartens, defined as net coefficient of enrollment, is rising. In 2003 , it constituted $78.0 \%$. This compares to $70 \%$ for nurseries in the same year. 
The mean number of children per kindergarten is 61 for the entire country. For cities, it is 99 and 29 for villages. The mean number of children in a kindergarten class is 22 , as for cities it is 23 and 18 for villages.

The pedagogical staff in kindergartens predominantly has a higher level of education, which is a prerequisite for greater opportunities to implement modern methods for the training and upbringing of children.

Few parents consider making use of private kindergartens (launched in the 1990s) as an alternative choice. According to official statistics, few children attend private kindergartens (605) but probably not all attendees are officially registered.

\subsection{Military and alternative civilian service system}

Countries differ considerably by the organization of their national defense system, with many countries having obligatory military service, usually with an option for alternative civilian service of the same duration or sometimes longer. Defense systems are highly gendered systems, especially compulsory services, usually only including men. Depending on the duration and flexibility of timing, military and civilian service interact with other life course careers, e.g., they may interrupt educational and job careers and delay other life course events, such as entering a job career, moving in with a partner and entering parenthood. As military and civilian service regulations may include exceptions or special treatments for people with family responsibilities or in special job positions or professions, the system also may interact with related life-course decisions in order to avoid individual service provision. The organization of military and civilian service has been subject to substantial change over time in many countries, and this enables the study of the policy impact of related regulations. In many countries with compulsory service, a considerable percentage of people opt for the alternative of civilian service. Depending on the nature of this service, civilian servants may be important providers of care services and therefore providers of welfare in addition to the state, family, market and voluntary sector usually listed in the concept of welfare pluralism.

The data collection of the contextual database mainly focuses on age norms (service age and service durations) of compulsory military and civilian services. Some variables capture the agency regarding compulsory military and alternative civilian service, e.g., restrictions for alternative civilian service, the flexibility of the timing and the existence or exclusion of females in armed forces.

\subsubsection{The Bulgarian military system}

During the socialist era, the countries of Central and Eastern Europe, including Bulgaria, were members of the Warsaw Pact. Their defense systems were built on the Soviet model fully dependent on it, and later depended on the Russian military industrial complex. 
Below, we point out some important elements of the military system in pre-transition Bulgaria:

- Obligatory military service for men only, irrespective of race, religiousness, the educational level, the social and marital status (with 18 being the conscription age).

- The duration of military service was two years (with the exception of the navy forces, for which service lasted three years).

- A subject on military training was part of the high school national curriculum.

After the Cold war and the collapse of the Warsaw Pact, a Declaration was signed on July $13^{\text {th }} 1990$ by which Bulgaria accepted an invitation to establish regular diplomatic relations with NATO. Fourteen years were needed for the Bulgarian military system to fulfill NATO requirements to become a member. On April, $2^{\text {nd }} 2004$, the official ceremony of accession of seven new countries, including Bulgaria, to the North Atlantic Treaty took place in Brussels. The years after the transition were characterized by an extremely unfavorable tendency in the structure and dynamics of demographic processes in Bulgaria, starting in the middle of 1980s. According to the statistics, the number of boys born in 1977 decreased from approximately 79000 to 33000 in 1997. Their numbers are expected to drop to 25000 in 2005. Add to this the number of people who have left the country since 1990, which is estimated to be about 500000 to 700 000, mainly young Bulgarian citizens.

Overcoming the early 1997 crisis in Bulgaria would have been impossible without radical reforms in all spheres, including defense. The structure, staff and number of the Bulgarian army and armed forces reached a critical inconsistency with the role, the aims, the budget and other resource abilities of the country. During the socialist time the ratio between military personnel and the civilian population used to be 1:85 - a figure that is much higher compared with other countries in the region (approx. 1:120) and twice as high compared to the ratio in the European Union (1:177).

At the end of 1997, the Bulgarian Armed Forces (BAF) started to be professionalized. By September 2000, it had 1032 professional soldiers. The total number of cadre soldiers and seamen in 2001 reached 3394 in the same year. The need for BAF professionalization arose from limited defense resources and manning needs of the armed forces, from shortterm conscription, a lack in training personnel how to handle and maintain complex combat equipment, the need for highly trained military specialists to participate in forces and missions for peace restoration and peacekeeping.

After the transition in 1989, the main features of the military system were:

- Obligatory military service for men only, no matter of race, religiousness, educational level, social or marital status (conscription age - the age of 18).

- The duration of military service was reduced to 9 months (6 months for graduated students). 
- An option to do alternative service instead of compulsory military service was introduced by an Act of Parliament.

- A professional army was created. By the end of 2001, it consisted of 3394 people.

\subsection{Unemployment}

As a mass phenomenon, unemployment first emerged alongside the industrial revolution. In the preceding centuries (and e.g. in the UK still until the beginning of the $18^{\text {th }}$ century), unemployment was frequently considered vagabondage and in case of recurrence subject to legal persecution up to execution. While unemployment is still not fully de-stigmatized in some societies, with the increasing recognition of social rights and the emergence of welfare state policies now focus on confronting social exclusion and poverty arising from unemployment and on the prevention of unemployment e.g., by active labor-market policies. Unemployment and unemployment risks effect many of the life-course behaviors studied in GGP. Unstable jobs and economic stress delay the transition to adulthood and may reduce fertility; however, unemployment spells and crises seen as temporal phenomena can also increase fertility, with parenthood being both a parallel and alternative career. (The latter was observed in Finland (Vikat 2004)). In post-communist countries like Bulgaria, unemployment is a new phenomenon and one of the factors behind the sharp decrease in fertility.

Unemployment is closely related to many welfare state dimensions. As a risk, it affects different population groups differently by age, sex, profession, education and employer (e.g., public employees may enjoy full protection from unemployment risks). Equality concepts are also to be found in different designs of unemployment systems, which are based on need (means-tested programs) or status (replacement of former income). Inequalities can also be found regarding agency: Certain population groups may have different levels of job security and access to labor markets, the latter also entailing discrimination of women, mothers, ethnic minorities and foreigners.

In the Contextual Database, we mainly focus on three aspects of unemployment: (1) unemployment rates by individual characteristics such as age, sex and education; (2) measures on the duration of unemployment; and (3) the main characteristics of the unemployment insurance system in terms of time, benefit level and entitlement conditions.

\subsubsection{Unemployment in Bulgaria}

Transformation from a centrally planned economy towards a market one brought in its wake some new processes and indicators. Unemployment was one of them. The very notion of unemployment was introduced relatively soon in the statistical surveys in Bulgaria, due to the fact that by 1989 the economy was characterized by almost full employment. Consequently, the statistical attributes employment and activity were 
practically identical in statistical research. In the 1985 census, the category "temporarily non-employed" was observed for the first time. Its definition does not coincide with the category unemployed. The NSI has been observing the employed and unemployed, strictly following ILO definitions, only since 1992.

Total unemployment increased rapidly at the very beginning of the country's transition period with the launch of structural economic and societal reforms. Unemployment first peaked in 1993, numbering as many as 650 thousand unemployed (a total unemployment rate of $15.8 \%$ ). The second peak was in 1997, owing to a very deep general economic crisis, with a total unemployment rate of $14 \%$. The third and the highest peak occurred in 1999-2001. It was caused by very intensive and real structural transformations - total unemployment rocketed to $18.1 \%$ in 2000 . By the end of the period under study, unemployment had increased in absolute and in relative figures compared to the respective indicators in 1990 (the total unemployment rate reached 14.3\% in 2003).

Unemployment affected equally both sexes at the beginning of the transition period, with a slight but constant rise in male unemployment (to 55\% in 2003). The outrunning growth rate of unemployed men in comparison to the respective indicator for women most probably came as a result of the higher capacity and ease of the latter to respond to the changing labor market conditions during the transition towards the market economy.

The age distribution of the unemployed has been characterized since the early 1990s by very high unemployment levels in the youngest age groups. In 1992, the unemployment rate for the whole age group under 29 was $28 \%$. It rose over the following years and reached above $32 \%$ at the end of the period. A similar but more intense rise in unemployment was noted throughout the period in the eldest age groups - from an unemployment rate of $7 \%$ for the age group over 50 in 1992 to $19 \%$ in 2003 . These agespecific peculiarities in unemployment were due to the transition period characteristics and related economic, social, institutional, organizational, etc. reforms and transformations in the country.

Since the beginning of 1990s, the urban-rural aspect of unemployment has been characterized with lower unemployment rates in towns (12\% in 2003) in comparison to those in villages (16\%). The main causes of this trend are found in the characteristics of the urban labor force that were more favorable than that of their rural counterparts: the rural labor force experienced profound and long-lasting ageing, constant emigration to towns of higher educated and younger actives, etc.), as well as wider employment opportunities in towns.

People with secondary education had the highest percentage among the unemployed (48\%) in 1992, followed by those with low education (44\%). These proportions changed to $53 \%$ and $36 \%$ respectively at the end of the period. The process is due to a lasting tendency in Bulgaria, namely, a reduction in the number of lowly educated people among the country's population and labor force throughout the period under study as well as fewer possibilities 
and lower flexibility in employment opportunities for these groups of population under conditions of high unemployment.

Among other features characterizing unemployment in Bulgaria, the following deserve mention. Firstly, the unmarried witnessed the highest percentage in unemployment distribution by marital status and it remained at the same level by the end of the period (30\% in 2001). It was followed by almost equal figures (in terms of value and growth rates) for the married and divorced (19\% and 18\% in 2001, respectively). Unemployment figures of the widowed increased the steepest over the period 1992-2003 - from 9\% to $24 \%$. Secondly, a high percentage of registered unemployed without the right to receive allowances or severance payments was observed, and so was an increase in the rate (from $67 \%$ in 1993 to $82 \%$ in 2003). Thirdly, the low amount of paid severance pays can be placed within the context of the economic realities in the country (for instance, in 1996 their value was defined by the labor force law regulations to $25-29 \%$ of the net average monthly wage). Fourthly, the payments received have been far below the subsistence level per capita (according to some evaluations, their level in 1996 was below 20\% of that minimum). A tendency of reduction of real value of receive payments has been observed. The main reason for this is that the minimal wage (set as a correcting basis in the calculation of unemployment payments) fell behind in comparison to inflation and even to the average wage growth. Fifth, the entitlement period to receive unemployment payments was also relatively short. Sixth, high unemployment rate differentiation among the national minorities was observed. In 1992, the highest total unemployment rates were among Gypsies $-39 \%$, and among Turks - 25\%, compared to $14 \%$ among Bulgarians. Last but not least, some unemployed do not register with labour bureaus because of the discouragement to obtain job resulting from long-term labour market stagnation.

\subsection{The tax and benefit system}

Tax-benefit systems influence labor market incentives, as they define the impact of alternative labor market behaviors on disposable individual and family income. The design of tax systems - especially the taxation of individuals vs. couples, - also influences the extent to which paid employment and unpaid household activities and care work are shared between partners. Couple taxation decreases the marginal tax rate of the higher earning (frequently male) partner, while making employment for the other partner less attractive. Tax allowances for single earner families and children as well as child benefit change income positions according to the family situation, and this applies also to the systems of individual taxation. Besides the horizontal redistribution of incomes between employees in different family configurations, tax systems to different degrees also redistribute incomes vertically between different income groups and between people at different stages of their economic life-cycle. 
As to the Contextual Database, we aim at characterizing the main features of tax-benefit systems and mayor changes over time by means of structured text description (which allows us to identify different periods) and some key indicators, such as the marginal income tax rate, the VAT rate, social security contribution rates and the general level of social expenditure. A policy measure described in more detail is child benefit.

\subsubsection{Taxes and social security in Bulgaria}

Social Insurance in Bulgaria was established more than a century ago (in 1891). The first social security legislation concerned pensions of state employees. As in other Eastern and Central European countries, the pre-transition Bulgarian state expropriated social security funds and provided income security principally through guaranteed employment and cash transfers for dependent groups, such as children, old age and disabled.

The transition to a market economy found the system unequipped to deal with the emerging economic risks. Furthermore, it has been overlaid by new social protection schemes, such as means-tested social assistance, and poverty etc. Not only did the number of social insurance programs increase since the start of the transition but also the number of people receiving income support from these programs rose dramatically. The need for reforms was in addition determined by considerable financial problems of the system and constant efforts to maintain its financial sustainability. The first stage of social security developments in Bulgaria after the democratic change was made in 1995 with the introduction of a law on the "Social Security Fund". This stage was passed under the sign of broader reforms in the social security system. In 2000 was adopted the Code on Mandatory Public Insurance administering with the organization, financing and functioning of the system. The Code covers all contingencies listed by the International Labor Organization (ILO) on social security (minimum standards), except healthcare (which is regulated by another legislation). The Code on Mandatory Public Insurance was reformed by a new Social Insurance Code, adopted in August 2003.

The overall impact of taxes and contributions can be summarized in terms of the tax wedge. The social insurance system provides benefits, subsidies and pensions that cover permanent or temporary invalidity, maternity, unemployment, old age and death. High levels of taxation on labour (including the impact of social contributions) have a negative impact on job creation and can depress demand for labor in the formal economy while also encouraging the growth of the black economy. Data taken from a quarterly bulletin of the Ministry of Labour and Social Policy shows that the main total contribution rate for the year 2002 is $42.7 \%$ (corresponding to workers' category 3), of which $32.2 \%$ are paid by the employer and $10.5 \%$ by the employee; $4 \%$ of the contribution goes to the unemployment fund, $6 \%$ to the health fund. This basic rate was applied up to a ceiling of 850 BGN (recently changed to $600 \mathrm{BGN}$ ). Above this amount, both employer's and employee's contributions rates decrease progressively. For the self-employed, total social security 
contributions are $29 \%$ or $32 \%$ of the gross income depending on the risks insured and these rates exclude the contribution to the health fund.

The current tax rates for personal income tax are 12\%, 22\%, 26\% and $29 \%$ depending on the taxation scale band. The minimum monthly taxable income is equal to the national minimum wage (120 BGN from the beginning of 2004).

Overall payroll contributions went up from $35 \%$ in 1990 to $47.5 \%$ in 1999 . In the mid1990s, new mandatory contributions were introduced while the contribution rates to unemployment insurance and to social security were progressively cut, with a reduction in 2001 when the overall contribution rate (including social insurance contributions, health and unemployment contributions) decreased to $42.7 \%$. The government's objective is to reduce social contributions further and progressively to achieve a 50/50 split between employers' and employees' share by 2009. The 80/20 ratio was changed as intended to $75 / 25$ in 2002 , but the overall contribution rate was left unchanged.

Steps were also taken in 2002 to reduce the overall tax burden on businesses. The corporate tax rate was lowered from $20 \%$ to $15 \%$ in January 2002. The compound tax rate including municipal taxes was also decreased from $28 \%$ to $23.5 \%$.

Given the level of economic development, the tax wedge and the tax-burden on labour are high. This signifies a major barrier to the creation of jobs, in particular at relatively low wages, and a disincentive for the unemployed or inactive to take up such jobs.

\subsection{Housing market and housing policy}

Housing market characteristics, such as house prices as well as mortgage and rent levels and the availability of housing of different dwelling types, in conjunction with housing policies impact the transition processes to adulthood, such as moving out from the parental home and co-residence with the partner and - directly or indirectly - the timing of fertility. Housing policies in the former centrally planned economies serve as a good example to demonstrate the direct impact of housing policies on the timing of fertility: they provided privileged access to housing for parents and therefore promoted relatively early fertility. Housing policies impact the housing market both on the supply side, e.g., due to the direct provision of public housing, and the demand side, e.g., due to cash benefits and state-aided housing finance instruments. Additional instruments are price and rent regulations, and these may result in very segmented housing markets, with rent levels for otherwise comparable housing units varying considerably, e.g., by the year in which contracts were concluded.

Housing policies have a strong life-cycle dimension, as most benefits are received in the early phases of the active life-cycle and repaid later in life via taxes or individual repayment schemes of state loans. In this respect, housing policies compensate for unequal relative housing costs over the life-cycle: Housing expenditure is usually highest in life- 
course phases that are characterized by low life-cycle incomes at the beginning of a job career, very often combined with a high degree of family obligations. Housing costs are highest at the beginning of tenancy or ownership in absolute terms, too, as traditional mortgage and rent instruments are usually front-loaded due to nominally fixed repayments and rents (or rents indexed at rates not considering economic growth). Rent controls often increase this effect, leading to highest rents for young contracts while protecting old rent contracts, with the additional effect of reducing mobility. Housing policies also facilitate access to housing for certain population groups by regulating access to public housing and by providing (subsidized) loans or securing loans to households which are credit rationed, i.e., households that do not have the credit ratings required by banks.

Intergenerational transfers within families are frequently linked to housing directly by passing housing wealth on to the young generation or indirectly by financially supporting the young. In this respect, housing policies also have a cross-sectional re-distributive effect towards households that can not count on these transfers (with the possible impact of crowding out private intergenerational family transfers of resources). Some countries have high rates and a strong tradition of owner-constructed housing, with work-power informally provided by friends and neighbors.

\subsubsection{Housing markets and policies in Bulgaria}

Housing policy is always closely related to and depends on other policy sectors such as the general legislative framework and the tax system etc. Key economic indicators illustrate that during the transition period the Bulgarian housing sector has contributed to a slow down in the economic recovery. In Bulgaria, individual housing construction and private ownership have traditionally been more important to the economy than in other countries in transition. The main cause for a reduction in private-sector investment in housing is the low level of household income compared to the high level of construction costs and house prices during the transition. The lack of a functioning system of mortgage loans is making matters worse for private households and other investors in housing. High inflation and the lack of political priority given to the special economic requirements of the housing sector are one of the factors that prevent this sector from contributing to a sustainable process of economic recovery in Bulgaria.

The present rent policy in Bulgarian public housing is regarded as a general indirect housing subsidy that is both socially and economically inefficient. The absence of a clearly defined housing allowance system is probably one of the most important factors that restrict rental policy in Bulgarian housing.

Concerning the prices a broad differentiation is evident. Prices for real estates in large cities such as Sofia, Varna, Plovdiv and Burgas, remain high, while in almost all other towns of the country there is a very serious slump in real estate prices. Large differences also exist between real estate prices in different districts of the capital: They are 
permanently growing in the city centre and the prestigious residential quarters but experience a slump or remain the same in the rest of the city. Statistical data indicate that the housing supply, measured in dwellings per 1,000 people, is acceptable even by western European standards.

In July 2000, in a bid to eliminate negative economic trends and attract greater foreign investment, the Bulgarian parliament approved government proposals to ease regulations on the real estate market. Amendments of the Property Bill will make it easier for foreigners to buy buildings. Foreign nationals cannot own or lease land in Bulgaria unless through a company that is wholly owned by Bulgarians. Foreign nationals are legally allowed to own buildings. Also, the parliament abolished the existing requirement for foreign nationals to obtain permission from the Minister of Finance before being eligible to purchase a real estate.

The slow and non-transparent process of privatization did not attract sufficient foreigners to the country, ready to settle down and expand their business. The constitutional restriction on foreigners to buy land plots, which is expected to be abolished in the coming years, still further aggravated the situation of the real estate market in Bulgaria. As a result, if in the 80s approximately 20000 family houses and apartments were built per year, at the end of the 90 s the construction shrank to 7000 units per year.

\subsection{Legal regulations of personal relations and family responsibilities}

This database domain concentrates on four areas of legal regulations that (a) define family responsibilities and (b) directly restrict, prohibit and regulate important behaviors and personal relations studied in GGP or by setting strong (e.g., tax) incentives.

The first area comprises legal restrictions on abortions, which vary considerably over time and between countries. The second considers the legal treatment of partnerships. We want to know, if partnership registration changes individual tax and benefit positions and if the state distinguishes between married and unmarried cohabitation and between two- and same-sex partnerships. The third area concerns divorce restrictions, such as waiting times and the custody of children. Additionally, we are interested in the presence of legal obligations to care for parents.

\subsubsection{Legal regulations of abortion, personal relations and responsibilities in Bulgaria}

During the socialist era, and particularly since the early 1970s, the state introduced pronatalist policies, including a regime of restrictions against abortions (allowed only for non-married women and women with more than two children). Since the early 1970s, the number of abortions exceeded the number of births and this trend lasted until the end of the 20th century. Abortion practices increased from 1990 to the middle of the decade, when a 
new law on abortions, passed by the Bulgarian Parliament in February 1990, removed the restrictions for legal abortion.

Because of the liberalizations of abortions, the National Statistical Institute started to publish every year detailed data on abortions. These data include abortions by age (the number of abortions by age specific groups), by reason (abortions on request, for medical reasons, spontaneous abortions) and by place of execution (state hospitals, private clinics, state non-hospital polyclinics). For the first time in the last 30 years, a reversed trend emerged after 1999. The number of abortions has decreased and births exceed abortions. A possible reason for this development may be the increasing use of modern contraceptives and the broadening activities and campaigns of family planning organizations in the country. Some experts argue that the perceived decrease in abortions in the last years is not a real one owing to unreliable registration of abortions in private clinics.

Abortions on request are fully affordable up to week 12 of pregnancy and women pre-pay them. Social security does not cover induced abortions, with the exception of complications following abortion. Here, social security provides for sick leave.

The tax system in Bulgaria is individually based and does not respect combined incomes of both spouses. The family based tax system has been implemented since 1.01.2005, with reductions in annual taxes according to the parity of children. The smallest percentage in tax reduction applies to the first child, it increases for the second and the third child, and for the next children tax reduction is equal to that of the first child.

Same sex marriages are not legal and there are no official statistics on registered partnerships.

All legal aspects of divorce are stated in the Family Code, articles 99-101. A formal request for divorce submitted to court is followed by the so-called reconciliation meeting at which both spouses are required to attend. This meeting takes place in court behind closed doors. During this meeting, the judge talks about the negative effects of divorce and pleads for reconciliation of the couple. No earlier than two months after the last reconciliation meeting, the court can appoint a new meeting for reconciliation. In case these meetings do not reconcile the couple, the court can start a suit no earlier than four months from the last reconciliation meeting. In case the court considers a harmful effect on the children, the spouses and the society because of the postponement the hearings can begin earlier.

Article 80 of the Bulgarian Family Code deals with the allocation of alimony for the period following divorce. However, article 79 states that alimony can be provided only for a nonworking member of the family who does not receive income from his/her own assets. Legal regulations on the alimony for ex-husbands/ex-wives are stated in article 83. Only the non-guilty ex-spouse is entitled to receive alimony. Former spouses can receive alimony only three years after the divorce. In special cases, the court can decide to prolong that period. In real life, there are very few cases when the court allocates the alimony to the wife. No court statistical data for that issue exist and it is not possible to provide valid 
percentage of alimonies given to wives. (This issue can be further examined in details by conducting interviews with judges in family courts and obtaining their expert evaluation).

Family Code article 69 (1) provides regulations concerning caring obligations for a dependent elderly. These regulations deal mainly with issues of moral nature. There are some regulations concerning this topic in the Law on Social Aid, article 2, (3).

\subsection{The education system}

Education plays a crucial role in demographic behavior, especially as to the timing of lifecourse events, and is closely linked to the concepts of human agency and autonomy. Most other life careers (i.e., household formation, marriage and parenting) usually start after leaving school. Education systems create important age norms owing to differences in the duration of compulsory schooling and durations of typical educational tracks. In economic terms, educational attainment is a key determinant of human capital and strongly influences economic success, but also general agency - the freedom to achieve - and autonomy, reflected in changing gender relations and family behavior. Historically, access to education was highly gendered; today, educational gender differences - e.g., measured by the share of men and women with tertiary education - no longer exist in many societies. In many industrialized countries, it is nowadays the gendered educational specialization rather than differences in the level and duration of education that - among other factors leads to gender differences in labor market prospects. In many countries we also observe overall educational expansion, with a greater number of people acquiring higher education, and this trend is followed by every subsequent birth cohort, therefore leading to considerable generational differences in the educational composition of the population.

Educational attainment is an indicator of differences between individuals on many dimensions: It may be a measure of talent, income potential, social status and class as well as individual autonomy, i.e., independence of partners, and perhaps also of general norms in society (Hoem et. al., 2001). Regarding the latter, education systems reflect basic concepts of society towards equality and social (educational) rights. Besides the crosssectional differentiation of living conditions, the concepts of equality also include equality of life chances, i.e., the distribution of opportunities, resources and capabilities - all of them closely linked to educational attainment and access to education. Equality concepts also refer to permanent social cleavages, i.e., class formation and the intergenerational transmission of life chances, produced by education. Despite general educational expansion in many countries, considerable differences in educational opportunities regarding the individual regional and social background persist in most of them. In a comparative study of changes in educational stratification in 13 industrialized countries, Shavit \& Blossfeld (1993) show that inequalities in educational opportunities have been remarkably stable since the early twentieth century. Research on Germany by Henz (1997) indicates that school careers, particularly transition rates following the completion of 
elementary schooling, are highly selective. Similar results have been found for Austria (Spielauer 2004b).

Education systems differ considerably in many aspects, as to (1) the school entrance age and the procedure of school enrolment, (2) the costs to parents and pupils/students, (3) the variety of educational tracks, (4) standards and variations in the quality of teaching, training and general supply and (5) access regulations. The differences reflect different welfare state regimes. For instance, the liberal regime type promotes equal opportunities predominantly by the very early institutionalization of education owing to preschool education and an early school entry age. The UK serves as a typical example; here compulsory school starts a year earlier than in Continental Europe. While such a system focuses on equal school starting conditions, higher education is typically left to private initiative and individual merit (e.g., as basis for student grants). No focus on pre- and early school education is found in conservative regimes, which usually differ to a large degree in that first school choices are taken at a very early age, leading to high intergenerational persistence of educational careers and attainments. Universalistic welfare states typically focus on educational rights. An exemplary policy is the Swedish right to obtain a secondary school diploma, a right that is also granted to adults by entitlements to paid leave to obtain this qualification.

The educational system heavily impacts parental commitment in terms of time and monetary resources spent and is therefore linked to underlying family models. Conservative welfare state regimes are frequently associated with the male breadwinner model and a highly differentiated public part-time school system usually provided at no or low cost and at high quality. Liberal welfare state regimes heavily rely on private markets, requiring high private educational investments in terms of money rather than parental time.

As to the Contextual Database, we aim at capturing various dimensions of education systems and outcomes as described above. The data can be divided into six parts. The first group of variables concerns various timing norms, including the school entry age, the duration of common and compulsory schooling as well as standard school hours (part-time vs. fulltime) and school days. The second is outcome-related: it considers enrollment rates and educational attainments. As a quality measure, we include a variable on students per teacher. Another group of variables focuses on university students and standard living arrangements, the extent to which they combine their studies with paid employment and the percentage of students receiving grants. The fifth group concerns education costs and expenditure and the way in which they are shared between the public and families. Public involvement in education is also measured as the share of public educational institutions by the number of students. The database also contains a structured text description of the main features of and changes in the education system. 


\subsubsection{The Bulgarian education system}

Teachers as key mediators and formative agents of the young generation have a central role to play in the transformation of Bulgarian society. One of the strengths of Bulgarian education is that the system is capable of providing education for the vast majority of children up to the age of 16 . The wide network of schools created in socialist times has been maintained, and there is virtually no lack of schools or teachers. Bulgaria has been able to maintain pre-1989 levels of pre-school enrolment (62\% of the $2-8$ age group), and statistics show that access to grades 1-4 is nearly universal (the gross enrolment rate stands at $102 \%$ ). However, gross enrolments at middle (grades 5-8) and secondary levels (9-12) decreased to $87 \%$ and $68 \%$ respectively.

Features of the education system are as follows:

- Age at which compulsory education starts: 6-7

- Age at which compulsory education ends: 16.

- Structure of the education system: Pre-school (not compulsory): ages 3-6, with some crèche provision for under-3s. Junior grades 1-4; middle [or 'pre-secondary'] grades 58. Grades 1-8 (called Primary8) cover the compulsory part of education, and are mostly provided in the same school. Secondary schools are of 4 main types: gymnasium grades 9-12; specialist high schools with profiles in particular curriculum areas - e.g., sciences, humanities - they often select students at the end of grade 7; vocational/technical schools and art schools, 3 or 4 years; vocational training schools, 2 or 3 years. Religious schools are recognized as equal to secular schools as long as they meet state requirements. Tertiary (higher) educational institutions that offer a 'bachelor' degree after 4 years of study and a master degree (1-2 years after completion of the bachelor degree).

- Examination/transition points: Children who complete junior education (grades 1-4) receive a leaving certificate from their school; at the end of full primary (grade 8), they receive a certificate (again based on internal assessment by teachers) that entitles them to continue into grade 9 . There are state matriculation exams at the end of grade 12; a new, external form of Matura was introduced in 2003.

- The official language in the schools is Bulgarian. However, after the transition in 1989, "children whose mother tongue is other than Bulgarian may, besides the compulsory study of the Bulgarian language, study their mother tongue in municipal schools under the protection and control of the state" (Art. 8(2) of the Public Education Act of 1999).

\footnotetext{
${ }^{8}$ The English translation of Art. 26 of the Public Education Act of 1991 (as amended through January 1999) uses these terms: Junior grades 1-4; Middle 5-8; Primary 1-8; Secondary 9-12; Specialized secondary 8-12; Comprehensive 1-12; Vocational and technical schools 8/9-12/13; Vocational training schools 7/8 for a 3year course, or 9-12 for a 4-year course, or vocational colleges 2 years if entered after completing Secondary; Sports schools; Art schools, Special schools.
} 
Pre-school education comes under the aegis of the Ministry of Education and Science (MES) and the inspectorates; below the age of 3, children are the responsibility of the Ministry of Health. Some groups (crèches) exist for children between the ages of 1-3 that come under the joint responsibility of both ministries. Most pre-schools for 3-7 year olds are connected with a specific primary school. There are about 104 private kindergartens in the country.

Concerning primary education together with all other limitations that impacted the value of schooling during the transitional period, pupils faced some barriers to school attendance after grade 4 or 8 . The most popular type of village school is junior school (1-4) plus middle (grades 5-8). The MES makes effort to retain junior schools in most of the villages, and to transport children to middle schools. The true picture is, however, that middle and secondary education is not fully accessible to rural children. It is possible that the decline in enrolment at the middle and secondary level is related to limited access (e.g., lack of transport).

Prior to 1990, Bulgaria's higher education system was strongly state controlled in terms of ideology, curricula and the organizational and administrative framework. Of the 30 higher education institutions, only three - the Universities of Sofia, Plovdiv and Veliko-Tarnovo were of multi-disciplinary nature in 1989. The others followed the specialized professional training institute model e.g., pedagogical, technological, agricultural, medical etc. The predominant course model was the Master's Degree, which usually was obtained after having followed a five-year course structure. Further graduate studies were highly selective, with the government determining the number of students to study for the degree of a "science candidate", equivalent to doctoral studies. Student enrolment in higher education was traditionally small, numbering 101000 in 1980. However, a spurt in student numbers took place in the 1980s, so that by 1988/89 almost 127000 students were enrolled. The importance of higher education rose notably after the transition (the number of students enrolled in the universities increased to 258000 in 2000).

As early as in 1990, the Academic Autonomy Act was passed. It provided a much more open, flexible and liberal development framework for higher education. Institutions were granted full autonomy, private institutions were authorized, courses could be developed without having to comply to designated standards, and fees for teaching were permitted. Over 100 new faculties were established, programs increased from 150 to 490, and five private universities were established. Student numbers expanded enormously within a short time, and now included students who were able to pay tuition fees, and who often were admitted on the basis of lower qualifications than the state-supported students. The total number of students in higher education increased from 127000 in 1988/89 to reach 248570 in 1995/96, an increase of about 95\%. Thus, the Academic Autonomy Act was replaced by the Higher Education Act in 1995. This was a much more regulatory measure which sought to establish a balance between the authority and responsibility of the state relating to higher education and what the state regarded as an appropriate degree of autonomy and freedom of the institutions in the conduct of their affairs. In 2001, there 
were 91 higher education institutions (Higher Schools) in Bulgaria. There are 47 universities and equivalent institutions, including 33 public universities and higher institutes, 6 military institutions, and 8 private universities. The Higher Schools are located in 26 towns throughout the country.

\subsection{Health}

The GGP collects detailed information on the personal health status, illness and chronic conditions, limitations of daily activities and care relations (given and received personal care and emotional support) of all household members, including parents and children and irrespective of co-residence. Relations with parents and children are captured on many dimensions, including meeting intensity, spatial distance, and relationship satisfaction. The GGP also collects information on the living arrangements of parents and value orientations on care responsibilities.

Contextual variables include crude measures on health risks that cannot be obtained from GGP data: life expectancy, healthy life expectancy as well as general, maternal and infant mortality. We also aim at describing the main features of the health system by the level of public and private health expenditure, the coverage of insurance systems, and by means of a structured (text) description of its organization and historic evolution.

\subsubsection{Health and healthcare in Bulgaria}

The health care system in Bulgaria has undergone radical changes in the 1990s. The health system moved from state run health practices in polyclinics and hospitals to individual and group health practices in pre-hospital care (the General Practitioner (GP) system), private run clinics and polyclinics, and state and municipally run hospitals and houses for medical care, state run centers for emergency aid and centers for psychiatric health. In the year 2000, the Bulgarian government launched a health insurance system, including a monthly health insurance, paid by the employee and the employer. Due to a change in the health system from a tax-oriented to an insurance-based system, people in Bulgaria who were not able to pay their insurance during the last four years will not have access to health care from now on, with the exception of emergency help. The health reforms have started in 1997 and are continuing to today, with forthcoming reforms in hospital care. In July 2004, the Parliament passed a new bill on public health that clearly states patients' rights. Although the health insurance system stipulates strictly what services the Insurance Fund covers and what the patients should pay, undeclared payments for health services in hospitals, laboratories and clinics still exist.

The radical changes in the health care system and the socio-economic state characterized by impoverishment of a great part of the population, long-term unemployment, unhealthy consumption of food (less consumption of meat, vegetables, milk, etc.), social stress, violence, etc. have negative effects on the health status of Bulgarians. Data from cross- 
comparative studies conducted in the 1990s (WVS, EVS) indicate that Bulgarians selfreport their health status on the lowest level.

Since the early 1990s until today, incidence and morbidity rates by tuberculosis, contagious diseases (e.g., viral hepatitis, sexually transmitted diseases (esp. syphilis)), and mental disorders have increased dramatically. There is also an increase in the morbidity rate leading to temporary loss of economic activity and to permanent loss of individual labor capacities (disability). Since the early 1990s, incidence rates and mortality rates by cardio-vascular diseases as well as by malignant diseases are on a permanent rise.

Life expectancy is an integrative indicator of the quality of life. In 1970, the life expectancy was 71.29 years and remained at almost the same level over the 1980s (71.09) and the 1990s (71.48), while in the Western countries, it permanently increased over the entire period. It reached the level of 72.17 in 2002 or $6-8$ years below the level of the indicator for the Western countries. For the entire period, the gender gap in life expectancy remained at the level of 4-5 years, while in the 1990s the gap expanded to 7 years. The gap widening is due to a decrease in male life expectancy by 2 years in the mid 1990s, which is considered to be an exceptional case in the new demographic history. An indicator for healthy life expectancy for the total population is 64.6 years in 2002 .

A decrease in maternal mortality has been continuing in Bulgaria since the 1970s. Maternal mortality remains at 44.69 deaths per 100000 live births in 1970; in 1980, the rate decreased to 21.06, and then went down to 20.92 in 1990 and to 16.54 again in 2002. The indicator's level stays comparatively high compared to the level in the Western countries.

Infant mortality followed a roller-coaster trend over the last decades - from 27.30 infant deaths per 1000 births in 1970 to 20.24 in 1980, and 14.77 in 1990. There was a slight increase in the mid 1990s (17.51 in 1997) and afterwards a decrease to 13.34 in 2002.

Health care facilities, medical specialists and hospital bed provision for the Bulgarian population remains at an appropriate quality level. Compared to some developed countries, the number of hospital beds per 100000 inhabitants in Bulgaria is almost twice as high as in Sweden (1061 beds in Bulgaria and 608 in Sweden (1995)). In spite of the well developed resources, esp. the number of hospital beds and medical specialists (due to an exaggerated development of in-patient care before the reforms start), health services in Bulgaria are not very effective. Due to the practice of undeclared payments for health care and health care reforms, people resort to health care mainly in cases of emergency. The changes in the health care system create significant barriers to regular medical check-ups and intensifying disparities in access to screening programs. One of the priorities of the National Health Strategy, adopted by the Council of Ministries in 2001, is to make the health insurance system more effective and to increase the percentage of expenditures on health in GDP (in $2002-4.8 \%$ ). 


\subsection{Elderly care}

As to elderly care, in the Contextual Database we focus on statistical norms, policies supporting informal care, and institutions. While general living arrangements by age are contained in the contextual domain on housing, some additional information is given on the percentage of elderly living in institutions and elderly receiving formal home care. As to health care policies, we collect information on public spending on elderly care and the existence and key features of selected measures, namely care allowances, pension benefits for care givers, and supportive measures for working care givers (e.g., paid and unpaid care leave). In difference to childcare benefits, care allowances are provided to people in need of care or alternatively directly to care providers - a distinction that affects the agency of elderly and their bargaining power in the organization of care. Besides the financial incentives for the provision of informal care, there exist legal obligations in some countries to care for parents. Information on these obligations and related financial responsibilities is contained in the contextual domain "legal regulations of personal relations".

\subsubsection{Elderly care in Bulgaria}

Low income, a high unemployment rate, high poverty and an increase in the number of people in need of social protection are some of the problems that Bulgaria is facing after the beginning of transition. The negative natural increase in the population, which started in the early 1990s $(-0.4 \%$ o), is still in progress (with a decrease of 46118 people or $-5.8 \%$ o in 2002). Thus, gradual ageing of the population continues. During the period 1995-2002, the percentage of people aged 65 and above increased from $15.2 \%$ to $17.0 \%$. In the age pyramid, the proportion of people aged 60 and over is slowly increasing. In 2002, this proportion was $22.5 \%$ compared to $20.4 \%$ in 1992. An unfavorable tendency of increase in the percentage of unemployment in the upper age groups (over the age of 55) was noted in the middle of 1990s. In 2002, this trend continues to today, with the total number of long-term unemployed people aged above 55 being 31404 . According to the last changes in pension legislation, the age needed for retirement will be increasing by 6 months yearly until 2009, when it will be 63 for men and 60 for women.

The Bulgarian family code obliges children to take care of their parents. Taking into account that Bulgarian society bears some traditional features and the family unit is still a major unit in our culture, traditions and values, we could say that the system of elderly care is not well developed. In fact, in Bulgaria there is a well-organized and working system of allowances and benefits oriented towards people with disabilities, which could be used as a basis for a new elderly care system. Even though there are no particular regulations regarding the elderly, Bulgarian legislation provides for social assistance of senior citizens. A Law on the Protection, Rehabilitation and Social Integration of the Disabled (promulgated State Gazette, issue 115 dated 1995) regulates elderly care aid. The following institutions serve as examples of the system of elderly care functioning in Bulgaria. 
- Day-care homes - which create conditions for the day care of persons with mental impairment, persons over 18 years of age with physical impairment with certified first or second group disability and for persons over 60 years of age;

- Homes for elderly persons - which provide social services to persons over 60 years of age, as well as to persons with impaired mobility or bedridden patients of the same age;

- Home social patronage - it provides services to persons over 60 years of age, persons with certified first or second group disability, and disabled children. Home social patronage includes food delivery, the maintenance of personal hygiene and hygiene of the premises, inhabited by the person attended, providing necessary assistance in case of disability or serious illness, assistance in the communication and the maintenance of social contacts, and rendering various everyday services.

\subsection{The political system}

The study of the political system reveals the dominant social values and normative concepts, which in multi-party systems are also reflected in the different programs and priorities of political parties. The development of welfare states involves and reflects the efforts and struggles of competing interest groups to gain political influence and to lobby policy makers to their course. The presence and power of certain groups reflect dominant value systems. Korpi (2000, 148p) distinguishes between three major political tendencies, namely confessional parties, secular conservative-centrist parties and left parties. Confessional parties are characterized by a high priority on the traditional family, which is seen as the moral basis of society and, compared to secular conservative parties, by a higher acceptance of redistribute market interventions in order to combat poverty. This list of major political tendencies can be extended, e.g., by rightwing populist movements; and the term "left parties" can also include a distinction between social democratic and socialist/communist parties, especially as the Generations and Gender Program covers former centrally planned economies, this in contrast to mainstream welfare state research

Typical measures of the strength of political tendencies include the percentage of government portfolios held and the percentage of duration inside and outside government and parliament. The Contextual Database gives the information needed to calculate such measures by providing descriptions of the main political parties and their representation in government (coalitions) over time.

\subsubsection{The political system of Bulgaria}

Bulgaria is a parliamentary republic. Political parties are registered according to the law on political parties, adopted in 1990, and prohibiting the founding of political parties based on ethnicity, race or religion. The $39^{\text {th }}$ Assembly of the Bulgarian Parliament, elected in the parliamentary elections in June 2001, consists of the following parliamentary groups: 
- National Movement Simeon the Second (98 members) - the largest parliamentary group

- Coalition for Bulgaria (49 members)

- United Democratic Forces (28 members)

- Movement for Rights and Freedoms (20 members)

- Union of the Democratic Forces (14 members)

- People's Union, Democratic Party (11 members)

- The New Time (13 members)

- Independent Members of Parliament (7 members)

The ruling coalition consists of the National Movement Simeon the Second and the Movement for Rights and Freedoms. The National Movement Simeon the Second is a new political formation of a centrist type that won the elections in 2001 (42\% of all votes) and was registered as a political party after the elections. The Movement for Rights and Freedoms was founded at the end of 1989 as an anticommunist political party which stands for liberal democracy, the free market economy, a socially oriented state and the defense of civil rights and freedoms of citizens from all ethnicities and religions. Most members and voters of this party are ethnic Turks.

The main opposition parties in the Bulgarian Parliament are: the Bulgarian Socialist Party, the largest parliamentary group in the 'Coalition for Bulgaria', the Union of Democratic Forces and the United Democratic Forces. The Bulgarian Socialist party, in coalition with other small parties, has identified itself as a leftist, social democratic party. The Union of Democratic Forces and the United Democratic Forces represent the right wing of the political spectrum. The Union of the Democratic Forces (including the United Democratic Forces) was the ruling party during 1997-2001.

Of the MPs, $72.5 \%$ are men and $27.5 \%$ are women. The distribution of MPs according to their professional status is as follows: $19 \%$ - engineers, 17\% - lawyers, $14 \%$ - economists, $13 \%$ - teachers, $11 \%$ - medical doctors, and $18 \%$ - from other professions.

The last local elections were held in November 2003. The majority of majors elected are from the Bulgarian Socialist Party, followed by the Union of Democratic Forces, and next the Movement for Rights and Freedoms, the National Movement Simeon the Second and independent candidates.

One of the main characteristics of Bulgaria's political landscape is a rapid proliferation of new political parties after 1989 (about 300). At the same time, only 5-6 of them have preserved their party name and label. About 2000000 voters have changed their votes during the elections after 1989. 


\subsection{Culture}

Concerning the cultural context, the contextual database gives information on the regional population composition by religious affiliation, language and ethnic group.

The ethnical structure of the Bulgarian population comprises ethnic Bulgarians, ethnic Turks, ethnic Gypsies (Roma) and others. According to the last Census in 2001, Bulgarians make $83.9 \%$ of the total population (7928901). The Turkish ethnic group represents $9.4 \%$, and Roma $4.7 \%$ and others $2 \%$ of the total population.

The structure of the population by residence and ethnic group shows that Bulgarians tend to inhabit the urban areas $(89.6 \%)$ more so than the rural areas $(70.1 \%)$. By contrast, the Turkish ethnic group inhabits villages four times more than urban areas (5.1\% to 19.3\%).

The greatest part of Bulgarians is concentrated in the South-West region (92.8\%) and in the North-West region (91.3\%). The Turkish ethnic group lives in the main in the NorthEast region (22.4\%) and South Central region (11.7\%). The Gypsy ethnic group has populated all regions, but a relatively large part of them (7.6\%) the South-East and SouthWest.

In accordance with the ethnic composition of the population, the main language in the country is Bulgarian (84.5\%). Turkish is a native language for $9.6 \%$ of the population and the Gypsy language is a native language for $4.1 \%$ of the population.

The official religion in Bulgaria is East Orthodox Christian. This religion is the dominant one for $82.6 \%$ of the population. A small part of the population is catholic $(0.6 \%)$ and protestant $(0.5 \%)$. As a whole, $83.7 \%$ of the population is Christians. The Muslim (Moslem) religion is the second religion that spreads the country $-12.2 \%$ of the population state that they belong to the Muslim denomination. Note that a small part of ethnic Bulgarians (mainly inhabiting the South-West region) and ethnic Roma people adhere to the Muslim denomination, as well.

\section{Acknowledgements}

We are thankful to Susann Backer for the careful language editing of this contribution. 


\section{Appendix: CDB variables}

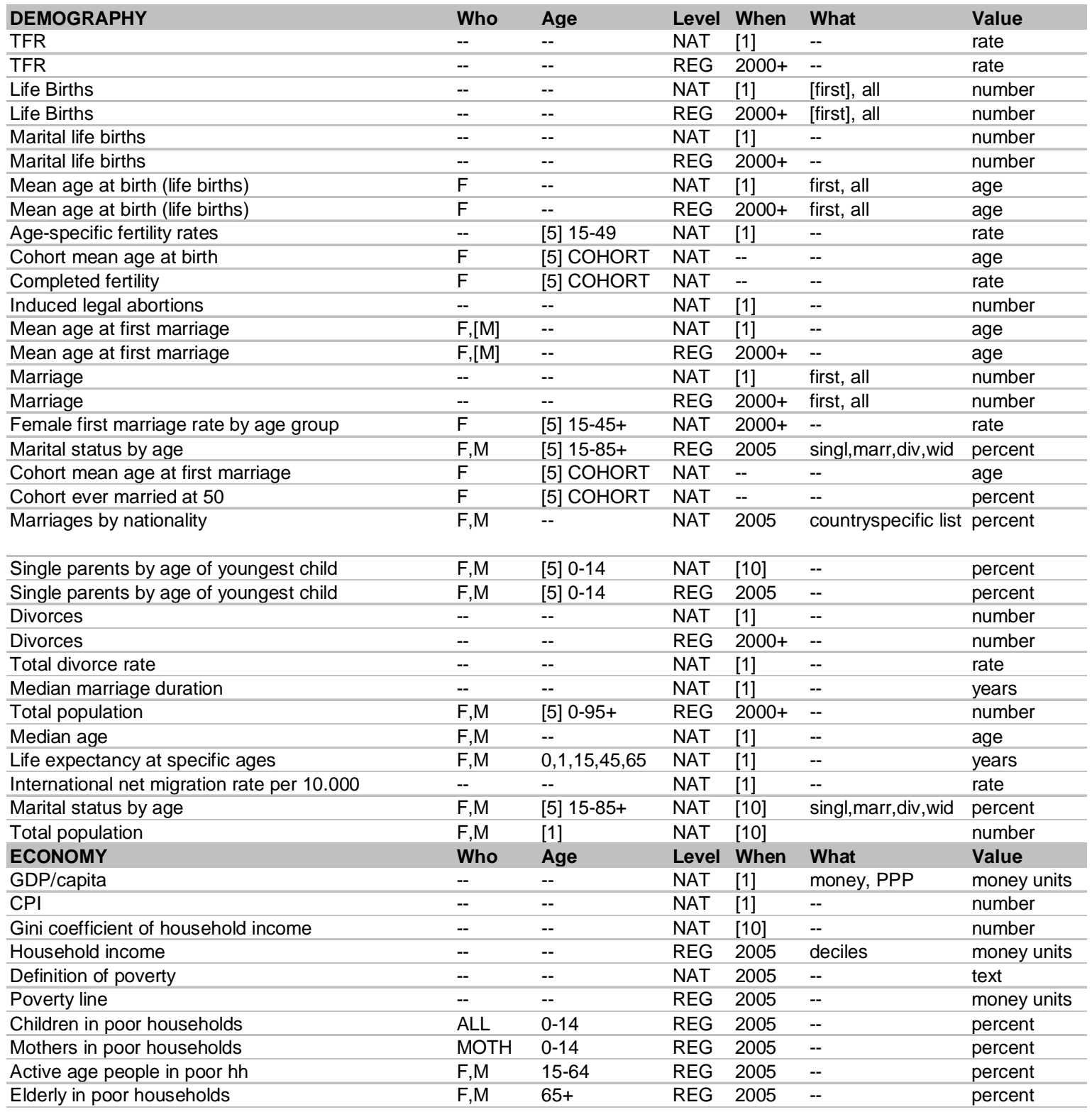




\begin{tabular}{|c|c|c|c|c|c|c|}
\hline LABOR & Who & Age & Level & When & What & Value \\
\hline Participation & $\mathrm{F}, \mathrm{M}, \mathrm{ALL}$ & $15-64$ & NAT & {$[1]$} & -- & percent \\
\hline Participation by age & $\mathrm{F}, \mathrm{M}, \mathrm{ALL}$ & [5] 15-65+ & REG & $2000+$ & -- & percent \\
\hline Participation of mothers by age of youngest child & $\begin{array}{l}\text { MOTH, } \\
\text { FATH }\end{array}$ & [3] 0-14 & REG & 2005 & $\begin{array}{l}\text { not working, in } \\
\text { leave, working }\end{array}$ & percent \\
\hline Sectoral Employment ISIC & $\mathrm{F}, \mathrm{M}, \mathrm{ALL}$ & -- & NAT & {$[10]$} & ISIC & percent \\
\hline Public Employment & $\mathrm{F}, \mathrm{M}, \mathrm{ALL}$ & -- & NAT & [1] & -- & percent \\
\hline Public Employment by age & $\mathrm{F}, \mathrm{M}, \mathrm{ALL}$ & [5] 15-65+ & REG & $2000+$ & -- & percent \\
\hline Employment by sex and occupational groups & $\mathrm{F}, \mathrm{M}, \mathrm{ALL}$ & all, $<35,>=35$ & NAT & {$[10]$} & ISCO & percent \\
\hline $\begin{array}{l}\text { Distribution of employed persons by usual weekly } \\
\text { hour bands }\end{array}$ & $\mathrm{F}, \mathrm{M}, \mathrm{ALL}$ & [5] 15-65+ & NAT & [10] & $\begin{array}{l}<19 h, 20-24,25- \\
29 h, 30-34 h, 35- \\
39 h, 40+\end{array}$ & percent \\
\hline Part-time employment of mothers & MOTH & [5] 0-14 & REG & $2000+$ & -- & percent \\
\hline Normal working hours & -- & -- & NAT & EVENT & -- & hours \\
\hline Minimum vacation days & -- & -- & NAT & EVENT & -- & days \\
\hline Average vacation days & -- & -- & NAT & EVENT & -- & days \\
\hline Entitled to part-time & -- & -- & NAT & EVENT & -- & text \\
\hline Measures to increase part-time & -- & -- & NAT & EVENT & -- & text \\
\hline Measures reducing nonstandard hours & -- & -- & NAT & EVENT & -- & text \\
\hline Measures to compensate for nonstandard hours & -- & -- & NAT & EVENT & -- & text \\
\hline Wages by economic activity & $\mathrm{F}, \mathrm{M}, \mathrm{ALL}$ & -- & NAT & [1] & ISIC & $\begin{array}{l}\text { money units, } \\
\text { PPP }\end{array}$ \\
\hline Minimum wage & -- & -- & NAT & [1] & -- & money units \\
\hline Average wage & $\mathrm{F}, \mathrm{M}, \mathrm{ALL}$ & -- & REG & $2000+$ & $\begin{array}{l}\text { nominal, } \\
\text { purchasing power } \\
\text { adjusted }\end{array}$ & money units \\
\hline Average wages by age & $\mathrm{F}, \mathrm{M}, \mathrm{ALL}$ & [5] 15-65+ & NAT & $2000+$ & -- & money units \\
\hline Wage distribution & $\mathrm{F}, \mathrm{M}$ & -- & NAT & {$[10]$} & deciles & money units \\
\hline Public expenditure in active labor market programs & -- & -- & NAT & [1] & -- & percent \\
\hline LEAVE & Who & Age & Level & When & What & Value \\
\hline Time before delivery & -- & -- & NAT & EVENT & $\begin{array}{l}\text { protect, replace, } \\
\text { flat }\end{array}$ & days \\
\hline Total time if taken by one partner & -- & -- & NAT & EVENT & $\begin{array}{l}\text { protect, replace, } \\
\text { flat }\end{array}$ & weeks \\
\hline Leave due to sick child & -- & -- & NAT & EVENT & $\begin{array}{l}\text { protect, replace, } \\
\text { flat }\end{array}$ & days \\
\hline Time that can be shared & -- & -- & NAT & EVENT & $\begin{array}{l}\text { protect, replace, } \\
\text { flat }\end{array}$ & weeks \\
\hline Extra time reserved for second partner & -- & -- & NAT & EVENT & $\begin{array}{l}\text { protect, replace, } \\
\text { flat }\end{array}$ & weeks \\
\hline Time of parallel leave & -- & -- & NAT & EVENT & $\begin{array}{l}\text { protect, replace, } \\
\text { flat }\end{array}$ & weeks \\
\hline Replacement rate & -- & -- & NAT & EVENT & replacement & percent \\
\hline Flatrate or minimum & -- & -- & NAT & EVENT & replace, flat & money units \\
\hline Maximum & -- & -- & NAT & EVENT & replacement & money units \\
\hline Eligibility regulations: birth order, means tests, etc. & -- & -- & NAT & EVENT & $\begin{array}{l}\text { protect, replace, } \\
\text { flat }\end{array}$ & text \\
\hline Eligibility rate of women giving birth & -- & -- & NAT & EVENT & $\begin{array}{l}\text { protect, replace, } \\
\text { flat }\end{array}$ & percent \\
\hline Number of deferrable weeks & -- & -- & NAT & EVENT & $\begin{array}{l}\text { protect, replace, } \\
\text { flat }\end{array}$ & weeks \\
\hline Deferrable until which age of child & -- & -- & NAT & EVENT & $\begin{array}{l}\text { protect, replace, } \\
\text { flat }\end{array}$ & years \\
\hline Extendable with part-time & -- & -- & NAT & EVENT & replace, flat & yes/no \\
\hline Shorter period with higher benefits & -- & -- & NAT & EVENT & replace, flat & yes/no \\
\hline Combinable with employment & -- & -- & NAT & EVENT & replace, flat & $\begin{array}{l}\text { no/hour } \\
\text { restriction/m } \\
\text { eans- } \\
\text { tested/yes }\end{array}$ \\
\hline Take-up rates & -- & -- & NAT & EVENT & $\begin{array}{l}\text { protect, replace, } \\
\text { flat }\end{array}$ & percent \\
\hline Average take-up time & -- & -- & NAT & EVENT & $\begin{array}{l}\text { protect, replace, } \\
\text { flat }\end{array}$ & weeks \\
\hline
\end{tabular}




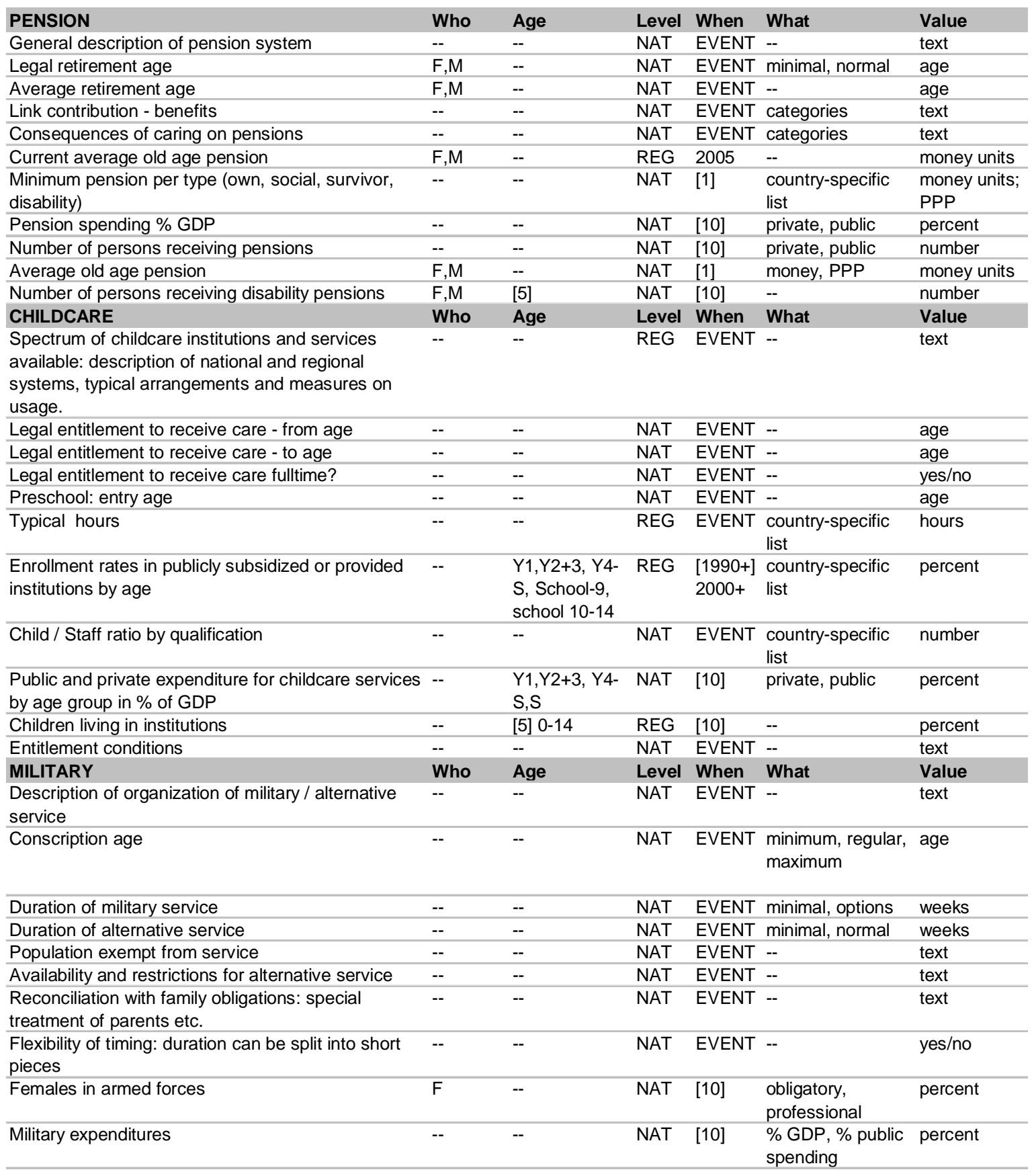














\section{References}

Bahle, T. \& Maucher, M., (1998). Developing a family policy database for Europe; Arbeitspapiere Arbeitsbereich I/27, Mannheimer Zentrum für Europäische Sozialforschung, Mannheim

Council of Europe (1999) Comparative Tables of the Social Security Schemes, - 9th edition

Esping-Andersen Gosta (1990) Three Worlds of Welfare Capitalism; Polity Press, Cambridge

Esping-Andersen, G., (1999) Social foundations of postindustrial economies. Oxford University Press, Oxford

European Commission (serial) MISSOC, Social Protection in the Member States of the Community. http://europa.eu.int/comm/employment_social/socprot/missoc99/english/f_main.htm

Ferrarini, Tommy (2003) Parental Leave Institutions in 18 Post-War Welfare States; Swedish Institute for Social Research, Dissertation Series 58

Festy, Patrick (2001) Designing a Macro-Context for the Generations and Gender Individual Data, Presentation at the first meeting of the Informal Working Group of the Generations and Gender Program in Budapest 2001 http://www.unece.org/ead/pau/ggp/fmiwg/festy.pdf.

Festy, Patrick (2004) GGP Contextual database group: first discussions, first conclusions; available from the author: festy@ined.fr

Gauthier, A.H. (2003). Comparative Family Benefits Database, Version 2 (University of Calgary).

Goldscheider, Frances K (2000) Realizing the Potential of FFS1 with Contextual Data, Presentation at the FFS Flagship Conference 2000, http://www.unece.org/ead/pau/flag/papers/goldscheider.pdf

Henz, U. (1997) Die Messung der intergenerationalen Vererbung von Bildungsungleichheit am Beispiel von Schulformwechseln und nachgeholten Bildungsabschlüssen. In: Becker, Rolf (edt.): Generationen und sozialer Wandel. Leske + Budrich, Opladen

Hoem, J.M., Prskawtz, A. and Neyer, G. (2001). Autonomy or conservative adjustment? The effect of public policies and educational attainment on third births in Austria. MPIDR WP 2001-016. Max Planck Institute for Demographic Research, Rostock

International Labour Office (1988). Work and Family: The Childcare Challenge. Conditions of Work Digest. Volume 7. Geneva 
International Labour Office (1994). Maternity and Work. Conditions of Work Digest. Volume 13. Geneva: International Labour Office

Korpi, Walter (2000) Faces of Inequality: Gender, Class, and Patterns of Inequalities in Different Types of Welfare States; Social Policies, Summer 2000

Marshall, Th., (1950). Citizenship and social class and other essays. Cambridge, Cambridge University Press

Neyer, Gerda (2002) Generations and Gender Dimensions in Welfare-State Policies, http://www.unece.org/ead/pau/ggp/smiwg/cdbasegr.pdf

Parsons, T. (1964). Social Structure and Personality, London: Free Press.

Racioppi, Filomena \& Rivellini, Giulia (2002) The contextual dimension in GGP: some methodological issues about data collection and sampling procedures http://www.unece.org/ead/pau/ggp/smiwg/cdbasegr.pdf

Shavit, Y. \& Blossfeld, HP. (1993) Persistent Inequality: Changing Educational attainment in Thirteen Countries. Boulder CO. Westview Press.

Spielauer, M. (2004b) Intergenerational Educational Transmission within families: analysis and microsimulation projection for Austria; Vienna Yearbook of Population Research, Vienna

US SSA (serial) Social Security Programs throughout the World. Washington, D.C : U.S. Dept. of Health, Education, and Welfare, Social Security Administration, Division of Program

Vikat, A. (2004) Women's labor force attachment and childbearing in Finland. MPIDR WP 2004-001 Max Planck Institute for Demographic Research, Rostock 